\title{
Arbeidspotentieel voor de politie, nu en in de toekomst
}

Citation for published version (APA):

van Breugel, G. A. A., \& Cörvers, F. (2010). Arbeidspotentieel voor de politie, nu en in de toekomst. ROA. ROA Reports No. 1 https://doi.org/10.26481/umarep.2010001

Document status and date:

Published: 01/01/2010

DOI:

10.26481/umarep.2010001

Document Version:

Publisher's PDF, also known as Version of record

\section{Please check the document version of this publication:}

- A submitted manuscript is the version of the article upon submission and before peer-review. There can be important differences between the submitted version and the official published version of record.

People interested in the research are advised to contact the author for the final version of the publication, or visit the DOI to the publisher's website.

- The final author version and the galley proof are versions of the publication after peer review.

- The final published version features the final layout of the paper including the volume, issue and page numbers.

Link to publication

\footnotetext{
General rights rights.

- You may freely distribute the URL identifying the publication in the public portal. please follow below link for the End User Agreement:

www.umlib.nl/taverne-license

Take down policy

If you believe that this document breaches copyright please contact us at:

repository@maastrichtuniversity.nl

providing details and we will investigate your claim.
}

Copyright and moral rights for the publications made accessible in the public portal are retained by the authors and/or other copyright owners and it is a condition of accessing publications that users recognise and abide by the legal requirements associated with these

- Users may download and print one copy of any publication from the public portal for the purpose of private study or research.

- You may not further distribute the material or use it for any profit-making activity or commercial gain

If the publication is distributed under the terms of Article $25 \mathrm{fa}$ of the Dutch Copyright Act, indicated by the "Taverne" license above, 


\title{
Arbeidspotentieel voor de politie, nu en in de toekomst
}

\author{
G. van Breugel \\ F. Cörvers
}

ROA-R-2010/1 
Colofon

(C) Researchcentrum voor Onderwijs en Arbeidsmarkt (ROA). Niets uit deze uitgave mag op enige manier worden verveelvoudigd zonder voorafgaande schriftelijke toestemming van de directeur van het ROA.

\section{Researchcentrum voor Onderwijs en Arbeidsmarkt}

School of Business and Economics

Maastricht University

\section{Vormgeving}

ROA secretariaat, Maastricht

\section{Verkoop}

Researchcentrum voor Onderwijs en Arbeidsmarkt email: secretary-roa-sbe@maastrichtuniversity.nl

website: www.roa.nl

ISBN: 978-90-532I-482-4

maart 2010 


\section{Inhoud}

Voorwoord

Management Samenvatting vii

1 Inleiding 1

1.1 Achtergrond onderzoek 1

1.2 Doelstellingen, onderzoeksvragen en analyse 3

1.3 Leeswijzer 5

2 Het arbeidspotentieel voor de politie tot nu toe 7

2.1 Definitie arbeidspotentieel voor de politie 7 2.2 Ontwikkeling potentiële zij-instromers met een politieverwante
opleiding

2.3 Vergelijking potentiële zij-instromers met een politieverwante opleiding en mensen met een politieopleiding $\quad 12$

2.4 Ontwikkeling potentiële zij-instromers werkzaam in een $\begin{array}{ll}\text { politieverwant beroep } & 14\end{array}$

2.5 Vergelijking politieverwant werkenden en werkenden bij de politie 16

$\begin{array}{ll}2.6 \text { Samenvatting } & 17\end{array}$

3 Het arbeidspotentieel voor de politie in de toekomst 19

3.1 Toekomstig arbeidspotentieel van schoolverlaters 19

3.2 Toekomstig arbeidspotentieel van potentiële zij-instromers met een politieverwante opleiding 25

3.3 Toekomstig arbeidspotentieel van potentiële zij-instromers werkend in een politieverwant beroep 28

$\begin{array}{ll}3.4 \text { Samenvatting } & 29\end{array}$

4 Waarom (niet) werken bij de politie: pull- en pushfactoren van een executieve politiefunctie 31

4.1 Mobiliteitsonderzoek: gegevens over instroom en uitstroom 31

4.2 Pullfactoren van een executieve politiefunctie 33

4.3 Pushfactoren van een executieve politiefunctie 44

$\begin{array}{ll}4.4 \text { Samenvatting } & 51\end{array}$

Bijlagen $\quad 55$ 



\section{Voorwoord}

Met het oog op toekomstig beleid voor het Nederlandse politiekorps heeft het Ministerie van Binnenlandse Zaken en Koninkrijksrelaties (BZK) het ROA verzocht om onderzoek te doen naar het arbeidspotentieel voor de politie. Met een focus op het 'blauw' ofwel de executieve politiefuncties, is vervolgens onderzocht hoe dit potentieel zich qua omvang (kwantitatief) en samenstelling (kwalitatief) zal ontwikkelen op de korte en middellange termijn. Daarnaast biedt deze rapportage een inkijk in de instroom- en uitstroommotieven van werknemers met een executieve politiefunctie ter ondersteuning van toekomstig wervings- en loopbaanbeleid voor de politiesector.

Het ROA wil een aantal personen bedanken voor hun input bij de totstandkoming van dit rapport: om te beginnen mevrouw $H$. van Kempen van de directie Kennis van BZK voor de begeleiding van het onderzoek. Vervolgens mevrouw M. Junte en de heer A. Verbree van de afdeling Arbeidszaken Publieke Sector (BZK) voor hun hulp bij het analyseren van de POMO-data en mevrouw V. Roelse van de KOSMOS Kennisbank (BZK). 



\section{Management Samenvatting}

Het Ministerie van Binnenlandse Zaken en Koninkrijksrelaties (BZK) heeft het Researchcentrum voor Onderwijs en Arbeidsmarkt (ROA) gevraagd onderzoek te doen naar (I) het arbeidsmarktpotentieel voor de politie nu en in de komende vijf tot tien jaar en (2) waarom mensen bij de politie willen werken of er juist vertrekken. Beide onderzoeksvragen hebben betrekking op het executieve politiepersoneel, degenen die werken in het primaire proces (inclusief hun leidinggevenden).

\section{Achtergrond onderzoeksvragen}

Inzicht in het (toekomstig) arbeidspotentieel is voor elke organisatie van belang omdat er vrijwel altijd een bepaalde vraag naar nieuw personeel is. De hoogte van deze vraag varieert in de loop der tijd, afhankelijke van diverse factoren. De vraag naar personeel bij de politie is onder andere afhankelijk van de mate van vergrijzing van het personeelsbestand, de mate van (vrijwillig) verloop en de politieke ambities. De politie krijgt in de (nabije) toekomst te maken met een flinke uitstroom van executief personeel wegens het bereiken van de pensioengerechtigde leeftijd van veel politiepersoneel. Immers, een kwart van het executieve personeel in 2007-2008 is 50 jaar of ouder. Daarnaast vertrekken personen ook om niet-pensioensgerelateerde redenen. Tot slot heeft de politiek enkele jaren geleden de wens uitgesproken de politiesterkte (bestaande uit executief én ondersteunend personeel) uit te willen breiden. De drie besproken factoren samen leiden ertoe dat de personeelsvraag vanuit de politie in de komende jaren eerder toe dan af zal nemen. Deze toename illustreert het belang van inzicht in zowel de kwantiteit als de kwaliteit (samenstelling) van het toekomstig arbeidspotentieel voor de politie. De tweede onderzoeksvraag sluit nauw aan bij de eerste. Immers, het identificeren van het toekomstig arbeidspotentieel is één, maar dit potentieel verleiden tot een baan bij de politie en ze vasthouden als ze eenmaal 'binnen' zijn, is twee. Een onderzoek naar zowel de in- als de uitstroommotieven van het politiepersoneel van de afgelopen jaren biedt aanknopingspunten voor een effectief wervings- en loopbaanbeleid zodat het potentieel optimaal kan worden benut nu en in de toekomst.

\section{Arbeidspotentieel}

In dit onderzoek is het arbeidspotentieel voor de politie gedefinieerd als personen met een mogelijke interesse in een executieve functie bij de politie, maar die niet in een 
dergelijke functie werkzaam zijn. Het potentieel wordt gezocht in twee groepen: de toekomstige schoolverlaters en de huidige beroepsbevolking. De mogelijke interesse van toekomstige schoolverlaters voor een executief politieberoep wordt afgemeten aan hun opleidingsrichting. Werkenden bij de politie blijken namelijk vaak een diploma van een beroepsopleiding uit de richting Openbare orde en veiligheid of een HAVO/ VWO-diploma te hebben. Naar verwachting zullen zich in de komende vijf jaar in totaal tussen de 16.000 en 24.000 schoolverlaters aanbieden op de arbeidsmarkt die interesse kunnen hebben in een zogenaamd politieverwant beroep (d.w.z. een executief beroep bij de politie, defensie of beveiliging). Waarschijnlijk zal ongeveer een derde hiervan interesse hebben in een politiefunctie. Concrete aantallen voor de jaren daarna zijn momenteel niet beschikbaar. Wel zal het aantal VMBO-gediplomeerden dat zich op de arbeidsmarkt aanbiedt dalen, terwijl het aantal HAVO/VWO'ers dat zich aanbiedt op de arbeidsmarkt zal stijgen. In de huidige potentiële beroepsbevolking bevindt zich ook arbeidspotentieel voor de politie. De interesse van deze personen voor een mogelijke politiefunctie wordt afgemeten aan hun opleiding (Openbare orde en veiligheid) en/of hun huidige beroep (een politieverwant beroep). Exclusief de personen met een politieopleiding en/of een politieberoep uit deze groep, blijft een groep van tussen de 60.000-80.000 personen over. Naar verwachting zal de omvang van deze groep licht afnemen in de komende tien jaar. Qua samenstelling zal het aandeel vrouwen, ouderen (50+), jongeren (30-) en niet-westerse allochtonen naar verwachting (licht) toenemen. Men dient zich te realiseren dat de personen in dit arbeidspotentieel vaak al een baan hebben. Zij zullen dus moeten worden verleid om bij de politie te komen werken.

\section{In-en uitstroommotieven}

Mensen die in het jaar 2003, 2005 of 2007 zijn begonnen in een executieve politiefunctie doen dit hoofdzakelijk omdat de inhoud van het werk hen aanspreekt. Andere belangrijke motieven zijn de verwachte zelfstandigheid/verantwoordelijkheid, ontwikkelingsmogelijkheden, relatie met collega's en de werkomstandigheden. Ook het werken op een hoger functieniveau, het werken van meer uren en (daardoor) een hoger salaris verdienen, lijken een rol van betekenis te spelen in de keuze voor een executieve functie bij de politie. Belangrijk om hierbij te vermelden is dat het belang van bepaalde motieven verschilt naar geslacht, leeftijd, herkomst of opleidingsniveau. Een analyse van data verzameld onder mensen die in het jaar 2003, 2005 of 2007 vertrokken zijn uit hun executieve politiefunctie, laat zien dat ook bij uitstroom (wederom) de inhoud van het werk en de ontwikkelingsmogelijkheden een belangrijke rol spelen. Hetzelfde geldt voor het werken op een hoger functieniveau en het verdienen van een hoger salaris. Daarnaast is de manier van leiding geven/besturen en de mate van resultaatgerichtheid van de organisatie een belangrijke reden om de huidige politiefunctie te verlaten. 
Tot slot

Het aanwezige arbeidspotentieel voor de politie nu en in de toekomst kan effectiever worden geworven en behouden door het betreffende beleid te differentiëren naar relevante doelgroepen zoals vrouwen, jongeren, ouderen en niet-westerse allochtonen. Zij blijken namelijk om deels verschillende redenen bij de politie te willen werken. Daarnaast is het voor de politie raadzaam om de positie van overheidssector te benutten juist als het in de private sector wat minder gaat. Het is dan waarschijnlijk eenvoudiger de juiste mensen aan te trekken (zowel schoolverlaters als potentieel dat al elders werkzaam is/was) dan in tijden van hoogconjunctuur. Een laatste maar belangrijk punt is dat het raadzaam is om het verband tussen de in- en uitstroommotieven nader te onderzoeken. Klopt het geschetste beeld dat men vooraf heeft over een executieve politie functie niet met de werkelijkheid of is er iets anders aan de hand? 



\section{Inleiding}

In opdracht van het Ministerie van Binnenlandse Zaken en Koninkrijksrelaties (BZK) heeft $R O A$ een onderzoek uitgevoerd naar het arbeidspotentieel voor de executieve functies van de politie, nu en in de toekomst en naar instroom-en uitstroommotieven van politiemensen werkend in een executieve politiefunctie. In de volgende paragrafen komen achtereenvolgens de onderzoeksachtergrond (paragraaf I.I), de onderzoeksdoelstellingen, de onderzoeksvragen en de benodigde analyses aan bod (paragraaf I.2). Dit hoofdstuk wordt afgesloten met een leeswijzer in paragraaf I.3.

\subsection{Achtergrond onderzoek}

In het kader van het Veiligheidsprogramma (2002) is afgesproken dat de sterkte van de Nederlandse politie uitgebreid wordt tot een omvang van ongeveer $52.500 \mathrm{fte}$ 's exclusief de functionele inzetbaarheid van aspiranten per 20I0. Ultimo 2008 bedroeg de politiesterkte zonder de functionele inzetbaarheid van aspiranten $52.322 \mathrm{fte}$ '. ${ }^{\mathrm{I}}$ Hiermee is de sterktedoelstelling voor eind 20Io bijna bereikt. Men verwacht dat de politiesterkte de komende jaren nog verder groeit en boven de beoogde streefwaarde voor eind 2010 uitkomt. Een belangrijke reden daarvoor is het grote aantal aspiranten dat op dit moment in opleiding is. Bovendien is per 15 maart 2008 de TOR (Tijdelijke Ouderen Regeling) beëindigd. Daardoor vindt in 2009 en 2010 aanzienlijk minder uitstroom van medewerkers door leeftijdsontslag plaats. ${ }^{2}$

De politie ligt qua sterkte dus goed op koers. Echter, enkele ontwikkelingen geven aan dat er nog niet op de lauweren gerust kan worden. Bij deze ontwikkelingen ligt de focus op het politiepersoneel in een executieve funtie. De recente ontwikkeling van de leeftijdsopbouw van het executieve personeel (zonder de aspiranten) laat zien dat het politiepersoneel vergrijst (zie figuur I.I). In vijf jaar tijd is het aandeel executief personeel van 55 jaar en ouder gestegen van $8,1 \%$ in 2003 naar $\mathrm{I} 2,5 \%$ in 2008 . Bovendien is in dezelfde periode het aandeel 50- tot 55-jarigen toegenomen van $14, \mathrm{I} \%$ naar $18,4 \%$. Oftewel, de leeftijdsopbouw is veranderd van 2 naar 3 van de Io politiemensen ouder dan 50 jaar in slechts vijf jaar tijd. De eerdergenoemde beëindiging van de TOR kan

I. De politiesterkte betreft al het personeel werkzaam bij de politie, dus inclusief het administratief, technisch en huishoudelijk personeel.

2. Ministerie van Binnenlandse Zaken en Koninkrijksrelaties (2009), Jaarverslag Nederlandse Politie (JNP) 2008, inclusief de Kerngegevens Nederlandse Politie, Den Haag. 
op korte termijn zorgen voor een geringere uitstroom van executief personeel. Op de middellange termijn echter, zullen deze mensen toch vanwege hun leeftijd uitstromen.

\section{Figuur 1.1}

Leeftijdsopbouw executief politiepersoneel (zonder aspiranten), als \% van het totale aantal fte's in het betreffende jaar, 2003-2008

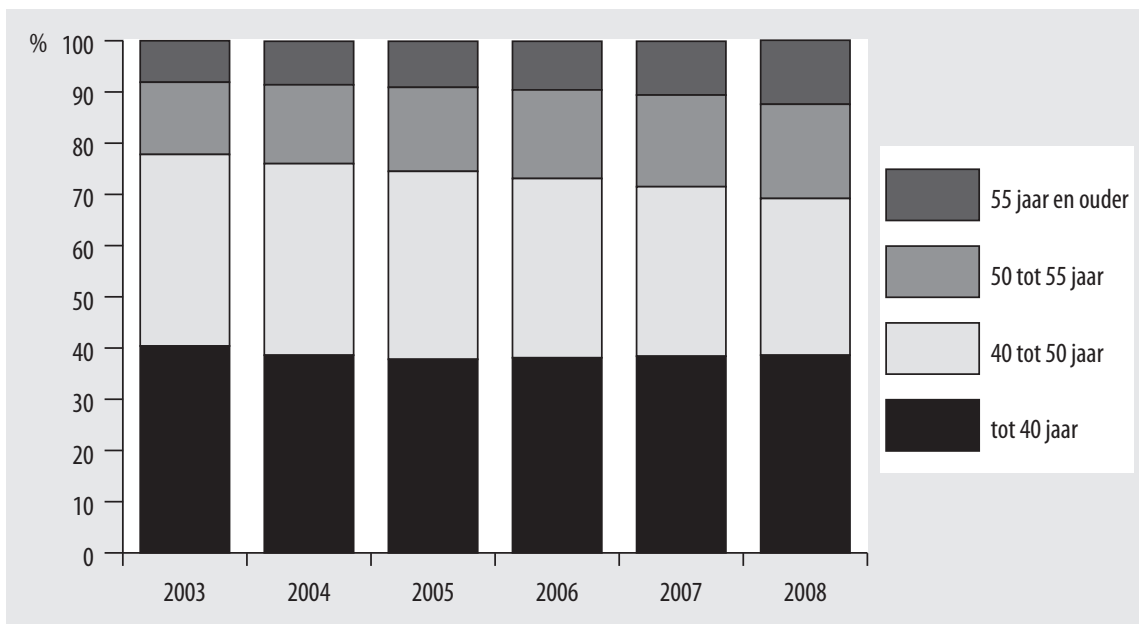

Bron: BZK (KOSMOS Kennisbank)

Een ander aspect betreft de eerder genoemde positieve ontwikkeling van het aantal aspiranten. Volgens cijfers van de Politieacademie is de instroom van het aantal studenten in de afgelopen jaren inderdaad gestegen van 2.218 studenten in 2002 naar 2.96I studenten in 2007. Echter, lang niet alle studenten die als aspirant aan de opleiding beginnen, maken deze ook daadwerkelijk af. Van de 4.I23 studenten die in 2002 of 2003 aan een opleiding binnen de Politieacademie begonnen, verlieten 802 studenten voortijdig de opleiding. Dit komt overeen met een uitvalpercentage van I9\%. Van deze uitvallers vertrok $42 \%$ vrijwillig. ${ }^{3}$

Naast vertrek uit de opleiding en pensionering, vertrekken mensen bij de politie ook om andere redenen (o.a. een baan bij een andere werkgever). De totale jaarlijkse uitstroom (inclusief uitstroom vanwege pensionering) bedroeg in 2007 5\%. Meer gedetailleerde gegevens over de uitstroom gedurende 2005 laten zien dat iets meer dan de helft van de uitstroom ( $53 \%)$ een niet-pensioengerelateerde reden heeft. ${ }^{5}$ Het totale

3. Politieacademie (2008), Jaarverslag 2007 Politieacademie, Apeldoorn.

4. Ministerie van Binnenlandse Zaken en Koninkrijksrelaties (2009), Kerngegevens Personeel Overheid en Onderwijs 2007, Den Haag.

5. Ministerie van Binnenlandse Zaken en Koninkrijksrelaties (2007), Personeels- en Mobiliteitsonderzoek Overheidspersoneel 2006, Den Haag. Deze cijfers hebben betrekking op al het personeel werkzaam bij de politie, niet enkel het executief personeel. 
uitstroompercentage van de politie als geheel is overigens vrij laag in vergelijking tot het gemiddelde voor de gehele sector overheid en onderwijs in 2007: 8\%.

Kort samengevat, hoewel het 'blauw' onmiskenbaar in omvang groeit, is het zaak om de vinger aan de pols te houden zodat de politiesterkte ook in de komende jaren op peil kan blijven. Daarom wordt in dit onderzoek om te beginnen geanalyseerd hoe de potentiële 'vijver' voor de sector politie zich in de komende vijf tot tien jaar zal ontwikkelen. Deze 'visvijver' bestaat uit personen die door hun opleidingsachtergrond en/of werkachtergrond geïnteresseerd zouden kunnen zijn in een loopbaan als executieve medewerker bij de politie. Daarnaast is het van belang om te weten wat mensen motiveert om bij de politie te werken of om er weg te gaan, zodat het arbeidspotentieel passend benaderd en begeleid kan worden om zodoende de instroom te maximaliseren en de uitstroom zo klein mogelijk te houden.

\subsection{Doelstellingen, onderzoeksvragen en analyse}

Het eerste doel van dit onderzoek is het beschrijven van het (toekomstige) arbeidspotentieel voor de politie. Er wordt gebruik gemaakt van data uit de Enquête Beroepsbevolking (EBB) van het CBS, administratieve gegevens van de politie gebaseerd op de personeels- en salarisadministratie (zoals in diverse rapportages van BZK en in de KOSMOS Kennisbank weergegeven), en het Arbeidsmarktinformatiesysteem (AIS) van het ROA. ${ }^{6}$ Het tweede doel van dit onderzoek is inzicht geven in de specifieke redenen die mensen hebben om in een executieve politiefunctie te beginnen of deze te verlaten. Voor dit doel wordt gebruik gemaakt van data verzameld door het Ministerie van BZK voor het Mobiliteitsonderzoek dat deel uitmaakt van het tweejaarlijks gehouden Personeels- en Mobiliteitsonderzoek (POMO).

De onderzoeksvragen die de basis voor het onderzoek vormen zijn de volgende:

- Hoe heeft de potentiële beroepsbevolking met een politie- of een daaraan verwante opleiding zich ontwikkeld in de periode 1996-2008 in vergelijking tot de potentiële beroepsbevolking en de potentiële beroepsbevolking met een politieopleiding?

- Hoe heeft de werkzame beroepsbevolking werkzaam in een politie- of een daaraan verwant beroep zich ontwikkeld in de periode 1996-2008 in vergelijking tot de werkzame beroepsbevolking en de werkenden in een executief politieberoep?

- Hoe zullen de potentiële beroepsbevolking met een politie- of een daaraan verwante opleiding en de werkzame beroepsbevolking werkzaam in een politie- of een daaraan verwant beroep zich ontwikkelen in de komende vijf tot tien jaar?

6. Door de korte doorlooptijd van dit onderzoek is het niet mogelijk gebleken om tijdig gegevens te verkrijgen over de jaarlijkse instroom- en uitstroom van de Politieacademie. 
- Welke schoolverlaters (naar opleidingstypen) zijn te beschouwen als arbeidspotentieel voor een executieve politiefunctie en hoe ontwikkelen deze groepen zich in de komende vijf jaar?

- Wat zijn de motieven om te starten in een executieve politiefunctie en wat zijn motieven om dezelfde functie op eigen initiatief te verlaten?

Bovenstaande onderzoeksvragen worden beantwoord met behulp van een aantal analyses. Ten eerste wordt er gestart met een analyse van de ontwikkeling van het deel van de (potentiële) beroepsbevolking dat een politieopleiding (aan de Politieacademie) óf een daaraan verwante opleiding heeft gevolgd. Het gaat hier in het bijzonder om opleidingstypen op VMBO-, MBO- en HBO-niveau in de richting beveiliging, openbare orde en veiligheid. Voor de analyses wordt gebruik gemaakt van gegevens uit de EBB vanaf 1996 tot en met 2008. Bovendien wordt gekeken naar de werkzame personen in beroepsgroepen die verwant zijn aan politieberoepen. Bij de analyses naar opleiding en beroep wordt gekeken naar de ontwikkeling van het aantal mensen met een voor de politie relevante opleiding, en naar het aantal personen dat werkzaam is bij de politie. Voorts wordt gekeken naar de achtergrondkenmerken wat betreft geslacht, leeftijd en herkomst. De gegevens uit de EBB worden gecombineerd met de eerder genoemde administratieve gegevens over de politie om een betere inschatting te kunnen maken van het deel van de (potentiële) beroepsbevolking dat daadwerkelijk werkzaam is bij de politie.

Ten tweede wordt er gebruik gemaakt van prognoses van de arbeidsmarktinstroom van gediplomeerden uit diverse relevante opleidingsrichtingen en niveaus (zoals de VMBO-, $\mathrm{MBO}$ - en $\mathrm{HBO}$-niveaus in de richting beveiliging, openbare orde en veiligheid). Deze prognoses zijn opgenomen in het zogenaamde Arbeidsmarktinformatiesysteem (AIS) van het ROA en geven de totale arbeidsmarktinstroom weer voor de vijfjaarsperiode tot 20I4. Op deze manier wordt een beeld verkregen van de toekomstige trends in het (potentiële) arbeidsmarktaanbod van de politie. Tevens zal via een meer kwalitatieve benadering een beeld worden geschetst van de verwachte ontwikkeling van dit arbeidsmarktaanbod in de vijfjaarsperiode vanaf 2014 .

Ten derde wordt gebruik gemaakt van de zogenaamde POMO-data die door het Ministerie van BZK zijn verzameld. Meer specifiek worden gegevens geanalyseerd van de groep instromers in een executief politieberoep om hun instroommotieven te achterhalen en van de groep vrijwillige uitstromers uit een executief politieberoep naar hun uitstroommotieven. 


\subsection{Leeswijzer}

De historische ontwikkeling van zowel de potentiële beroepsbevolking met een politieof een daaraan verwante opleiding als de werkzame beroepsbevolking werkzaam in een politie- of een daaraan verwant beroep, worden beschreven in hoofdstuk 2. In hoofdstuk 3 volgt de toekomstige ontwikkeling in beide groepen voorafgegaan door een prognose van de relevante groepen toekomstige schoolverlaters. Tot slot wordt in hoofdstuk 4 ingegaan op de instroom- en uitstroommotieven van politiemensen werkend in een executieve functie. 



\section{Het arbeidspotentieel voor de politie tot nu toe}

In dit hoofdstuk wordt beschreven wie tot het arbeidspotentieel van de politie wordt gerekend en hoe dit arbeidspotentieel zich qua omvang en kenmerken ontwikkeld heeft in de periode 1996-2008. In paragraaf 2.I wordt het arbeidspotentieel voor de politie gedefinieerd. Vervolgens wordt de historische ontwikkeling van het potentieel met een politieverwante opleiding geschetst in paragraaf 2.2 gevolgd door een vergelijking van dit potentieel met degenen die een politieopleiding gevolgd hebben (zie paragraaf 2.3). De ontwikkelingen in het verleden van het potentieel dat een politieverwant beroep uitoefent, staan in paragraaf 2.4. Paragraaf 2.5 vergelijkt het potentieel met een politieverwant beroep met degenen die daadwerkelijk bij de politie werken in een executieve functie. Een samenvatting van dit hoofdstuk is tot slot te vinden in paragraaf 2.6.

\subsection{Definitie arbeidspotentieel voor de politie}

Het arbeidspotentieel voor de politie bestaat uit personen die een mogelijke interesse hebben in een executieve functie bij de politie, maar niet in een dergelijke functie werkzaam zijn. Deze interesse voor een executieve politiefunctie wordt enerzijds afgemeten aan de opleidingsrichting die een persoon heeft gevolgd. Het gaat dan om de opleidingsrichtingen $\mathrm{VMBO}$ Beveiliging, $\mathrm{MBO}$ Openbare orde en veiligheid en HBO Openbare orde en veiligheid. ${ }^{\mathrm{I}}$ In het vervolg van dit rapport zullen deze drie opleidingsrichtingen samen worden aangeduid met de term "politieverwante opleidingen".

Anderzijds wordt de interesse voor een executieve politiefunctie bepaald door te kijken naar het huidige beroep van een persoon. Specifiek wordt gekeken naar beroepen die behoren tot de volgende drie beroepsgroepen uit de Standaard Beroepen Classificatie van het CBS:

- Aspirant politieagenten, soldaten en beveiligingshulpkrachten

- Politieagenten, onderofficieren en beveiligingsemployés

- Politie-inspecteurs en officieren ${ }^{2}$

I. Naast de politieopleidingen van de Politieacademie vallen onder deze opleidingsrichtingen o.a. opleidingen op het gebied van redding en opruiming, brandweer, zeemacht, landmacht, luchtmacht, etc.

2. Een volledig overzicht van de beroepen in deze drie beroepsgroepen staat in Bijlage B2.I. 
Deze drie beroepsgroepen bevatten zowel de politieberoepen als ook beroepen die verwant zijn aan de politieberoepen. In het vervolg zullen deze drie beroepsgroepen worden aangeduid met de term "politieverwante beroepen".

Het arbeidspotentieel wordt dus bepaald aan de hand van de gevolgde opleidingsrichting en/of het huidige beroep. Op basis hiervan kunnen in het arbeidspotentieel een aantal subgroepen worden onderscheiden. De eerste subgroep bestaat uit mensen die in het verleden een politieverwante opleiding hebben gevolgd, maar niet in een executieve politiefunctie werkzaam zijn (potentiële zij-instromers met een politieverwante opleiding). De tweede groep bestaat uit mensen die werkzaam zijn in een politieverwant beroep, maar niet in een executief politieberoep. We noemen hen de potentiële zij-instromers werkzaam in een politieverwant beroep. Hierbij dient opgemerkt te worden dat er overlap zal zijn tussen beide groepen potentiële zij-instromers. Een derde belangrijke subgroep in het arbeidspotentieel van de politie wordt gevormd door de toekomstige schoolverlaters: degenen die in de komende vijf jaar hun opleiding zullen afronden en zich zullen aanbieden op de arbeidsmarkt. Deze groep zal uitgebreid worden besproken in hoofdstuk 3 .

In het vervolg van hoofdstuk 2 zal een beeld geschetst worden van de ontwikkeling van beide groepen potentiële zij-instromers in de periode 1996-2008 qua omvang en naar enkele achtergrondkenmerken (geslacht, leeftijd, etc.). De ontwikkeling van de potentiële zij-instromers met een politieverwante opleiding zal vervolgens worden vergeleken met de ontwikkelingen in de groep mensen met een politieopleiding. Vervolgens zal de ontwikkeling van de potentiële zij-instromers werkzaam in een politieverwant beroep worden gelegd naast de ontwikkelingen in de groep werkenden in een executief politieberoep. De beschreven analyses zullen uitgevoerd worden op data afkomstig uit de Enquête Beroepsbevolking (EBB) van het CBS en data afkomstig uit de Kerngegevens Overheid van het ministerie van Binnenlandse Zaken en Koninkrijksrelaties (BZK).

Het doel van de beschrijvende analyses is drieledig. Ten eerste verkrijgt men op deze manier inzicht in de recente (2008) omvang en kenmerken van het arbeidspotentieel van de politie. Ten tweede worden mogelijke trends zichtbaar door het bestuderen van de ontwikkelingen in de periode 1996-2008. Deze trends kunnen ons vertellen hoe het arbeidspotentieel zich in de nabije toekomst zal ontwikkelen. Tot slot kan een vergelijking tussen het arbeidspotentieel en degenen die daadwerkelijk bij de politie werkzaam zijn of een politieopleiding gevolgd hebben, verschillen of overeenkomsten aan het licht brengen die relevant zijn in het uitstippelen van een strategie hoe dit arbeidspotentieel het best te benaderen. 


\subsection{Ontwikkeling potentiële zij-instromers met een politieverwante opleiding}

Om een indruk te krijgen van de potentiële zij-instromers met een politieverwante opleiding, wordt de potentiële beroepsbevolking als uitgangspunt genomen. De potentiële beroepsbevolking betreft hier alle mensen die ouder zijn dan I5 en jonger dan 65 jaar. Het gaat dus om personen die in potentie kunnen werken, maar lang niet iedereen doet dat ook. Zo bestond de potentiële beroepsbevolking in 2007-2008 uit bijna II miljoen personen, terwijl de werkzame beroepsbevolking in dezelfde periode ruim 7,3 miljoen personen bevatte. Van de potentiële beroepsbevolking is vervolgens iedereen geselecteerd die een politieverwante opleiding heeft gevolgd, dat wil zeggen een opleiding uit de richtingen VMBO Beveiliging, $\mathrm{MBO}$ en $\mathrm{HBO}$ Openbare orde en veiligheid. Het resultaat van deze selectie is te zien in tabel 2.I. Bij het lezen van deze tabel dient men in het achterhoofd te houden dat een deel van deze personen waarschijnlijk al werkzaam is bij de politie en strikt genomen dus niet tot het arbeidspotentieel voor de politie gerekend moet worden (zie tabel 2.2). Hier wordt in paragraaf 2.3 op teruggekomen.

Qua omvang schommelt de groep potentiële zij-instromers met een politieverwante opleiding in de periode 1996-2008 vrijwel constant rond de 100.000 personen. In de laatste twee jaar is echter een toename te zien. Wat de achtergrondkenmerken betreft, laat tabel 2.I zien dat het hier voornamelijk om mannen gaat, maar het aandeel vrouwen neemt gestaag toe tot $\mathrm{I} 4 \%$ in de jaren 2005-2008. De gemiddelde leeftijd is over de jaren licht toegenomen, maar niet zoveel als men misschien zou verwachten. Dit wordt veroorzaakt door twee trends die elkaar grotendeels opheffen: aan de ene kant neemt het aandeel 50-64 jarigen toe tot $35 \%$ in $2007-2008$, maar aan de andere kant neemt ook het aandeel I 5 -29 jarigen toe. $18 \%$ van de potentiële zij-instromers met een politieverwante opleiding was in 2007-2008 jonger dan 30 jaar.

In de hele periode bestaat de groep gemiddeld voor $85 \%$ uit personen van autochtone afkomst. Het aandeel personen van allochtone afkomst is dus ook gelijk gebleven, echter de samenstelling is enigszins gewijzigd: het aandeel niet-westerse allochtonen is gestegen, terwijl het aandeel westerse allochtonen is gedaald. Tot slot is het leeuwendeel van de mensen in deze groep op MBO-niveau opgeleid. Dit aandeel is wel kleiner geworden in de afgelopen jaren. Deze afname is zowel ten goede gekomen aan het aandeel VMBO- als aan het aandeel HBO-geschoolden. Beide groepen zagen hun aandeel toenemen in de periode 1996-2008. 
Tabel 2.1

Ontwikkeling potentiële zij-instromers met een politieverwante opleiding, 1996-2008

\begin{tabular}{lcccccc} 
& $1996-$ & $1998-$ & $2000-$ & $2002-$ & $2005-$ & $2007-$ \\
& 1997 & 1999 & 2001 & 2003 & 2006 & 2008 \\
& & & & & & \\
\hline $\begin{array}{l}\text { Potentiële beroepsbevolking met } \\
\text { politieverwante opleiding (in personen) } \\
\text { als \% van de potentiële beroepsbevolking }\end{array}$ & 100.000 & 97.500 & 101.500 & 100.000 & 97.000 & 105.500 \\
& 0,95 & 0,92 & 0,94 & 0,92 & 0,88 & 0,96 \\
\hline $\begin{array}{l}\text { Geslacht } \\
\text { Man }\end{array}$ & $\%$ & $\%$ & $\%$ & $\%$ & $\%$ & $\%$ \\
Vrouw & & & & & & \\
\end{tabular}

\begin{tabular}{|c|c|c|c|c|c|c|}
\hline Leeftijd & & & & & & \\
\hline 15-29 jaar & 12 & 11 & 11 & 11 & 16 & 18 \\
\hline 30-49 jaar & 59 & 58 & 57 & 54 & 48 & 47 \\
\hline 50-64 jaar & 29 & 31 & 32 & 35 & 36 & 35 \\
\hline Gemiddelde leeftijd (in jaren) & 42,9 & 43,2 & 43,5 & 44,2 & 43,6 & 43,2 \\
\hline
\end{tabular}

$\begin{array}{lrrrrrrr}\text { Herkomst } & & & & & & \\ \text { Autochtonen } & 85 & 84 & 84 & 85 & 86 & 84 \\ \text { Westerse Allochtonen } & 10 & 11 & 9 & 8 & 7 & 7 \\ \text { Niet-westerse Allochtonen } & 5 & 5 & 7 & 7 & 6 & 9\end{array}$

$\begin{array}{lrrrrrr}\text { Politieverwante opleiding } & & 6 & 10 & 9 & 10 & 9 \\ \text { VMBO beveiliging } & 5 & 9 & 85 & 86 & 80 & 80 \\ \text { MBO Openbare orde en veiligheid } & 92 & 90 & 5 & 5 & 10 & 11 \\ \text { HBO openbare orde en veiligheid } & 3 & 4 & 5 & \end{array}$

* De getallen in personen afkomstig uit de EBB van het CBS worden telkens afgerond op 50o-tallen. Bron: $\mathrm{CBS}(\mathrm{EBB})^{3}$

Vanwege de publieke functie van de politie wenst de politiek dat de personen werkzaam in een executieve politiefunctie een afspiegeling vormen van de maatschappij. In hoeverre vormt deze potentiële groep zij-instromers met een politieverwante opleiding inderdaad een afspiegeling van de maatschappij? Een vergelijking van deze groep met de potentiële beroepsbevolking (zie tabel B2.2 in de bijlage) laat zien dat dit niet helemaal het geval is. Om te beginnen zijn vrouwen in de groep potentiële zij-instromers flink ondervertegenwoordigd: de man-vrouw verdeling in de potentiële beroepsbevolking is namelijk 50-50\% en in de groep zij-instromers $86 \%$ - $14 \%$ (2007-2008). Daarnaast is de groep potentiële zij-instromers gemiddeld een paar jaar

3. In de EBB-data wijken de waardes voor 2004 sterk af van de waardes in de omringende jaren, vooral bij subgroepen op basis van opleidingsrichtingen en beroepsgroepen. Dit wordt waarschijnlijk veroorzaakt door de invoering van een nieuw sectorindelingssysteem van het CBS in 2004. Om die reden ontbreken gegevens voor het jaar 2004. Tevens is wegens de volatiliteit in de jaarlijkse EBB-data gekozen voor tweejaarsgemiddelden in plaats van jaargegevens. 
ouder dan de potentiële beroepsbevolking: in 2007-2008 was het verschil 3,2 jaar. Ook bevat de groep potentiële zij-instromers met een politieverwante opleiding een iets kleiner aandeel allochtonen (met name niet-westerse allochtonen) dan de potentiële beroepsbevolking in zijn geheel. Tot slot zijn de potentiële zij-instromers gemiddeld beter opgeleid dan de potentiële beroepsbevolking: in 2007-2008 had 80\% van de potentiële zij-instromers een opleiding op $\mathrm{MBO}$ - en $9 \%$ een opleiding op VMBOniveau afgerond, terwijl van de potentiële beroepsbevolking $4 \mathrm{I} \%$ een opleiding op $\mathrm{MBO}$-niveau en $32 \%$ een opleiding op VMBO-niveau heeft. Kort samengevat zijn vrouwen, jongeren, (niet-westerse) allochtonen en lager opgeleiden ondervertegenwoordigd in de groep potentiële zij-instromers met een politieverwante opleiding.

Aan het begin van deze paragraaf is al opgemerkt dat van de potentiële beroepsbevolking een belangrijk deel werkzaam is, maar een deel ook niet. Naast de werkzame beroepsbevolking bevat de potentiële beroepsbevolking namelijk ook nog de werkloze beroepsbevolking, de beschikbare niet-beroepsbevolking ${ }^{4}$ en de niet-beschikbare beroepsbevolking. Deze laatste groep bestaat uit mensen die niet binnen twee weken aan een baan kunnen beginnen (zoals arbeidsongeschikten). Er is dus wat voor te zeggen om deze groep niet als arbeidspotentieel voor de politie mee te tellen. Tabel 2.2 laat zien dat $13 \%$ van de potentiële beroepsbevolking met een opleiding MBO openbare orde en veiligheid niet beschikbaar is voor de arbeidsmarkt. Onder de potentiële beroepsbevolking met een VMBO-opleiding beveiliging is dit percentage waarschijnlijk hoger dan $\mathrm{I} 3 \%$ en onder de potentiële beroepsbevolking met een $\mathrm{HBO}$-opleiding openbare orde en veiligheid is dit percentage waarschijnlijk lager dan I3\%. Tabel 2.2 laat ook zien dat naarmate het opleidingsniveau onder de potentiële beroepsbevolking met een politieverwante opleiding hoger wordt, er relatief meer mensen werkzaam zijn.

\section{Tabel 2.2}

Samenstelling van de potentiële beroepsbevolking met een politieverwante opleiding (\%), 20072008

\begin{tabular}{lccc|} 
& VMBO beveiliging & $\begin{array}{c}\text { MBO openbare orde en } \\
\text { veiligheid }\end{array}$ & $\begin{array}{c}\text { HBO openbare orde en } \\
\text { veiligheid }\end{array}$ \\
\hline Werkzame beroepsbevolking & 74 & 82 & 91 \\
\hline Werkloze beroepsbevolking & - & 2 & - \\
\hline Beschikbare niet-beroepsbevolking & - & 3 & - \\
Niet-beschikbare niet-beroepsbevolking & $>13$ & 13 & - \\
\hline Potentiële beroepsbevolking & - & 100 & -13 \\
\hline
\end{tabular}

* Helaas is deze informatie niet beschikbaar voor de opleidingsniveaus VMBO en HBO. Echter, gegevens van andere opleidingsrichtingen in het AIS laten zien dat over het algemeen het aandeel niet-beschikbare niet-beroepsbevolking bij het opleidingsniveau VMBO hoger en bij het opleidingsniveau $\mathrm{HBO}$ lager is dan bij het opleidingsniveau MBO.

- Deze informatie is niet in AIS beschikbaar wegens te kleine aantallen respondenten.

Bron: ROA (AIS)

4. De werkloze beroepsbevolking bestaat uit personen die willen werken, beschikbaar zijn en zoeken naar werk voor ten minste I2 uur per week en de beschikbare niet-beroepsbevolking bestaat uit alle personen in de niet-beroepsbevolking die binnen twee weken in een nieuwe werkkring kunnen beginnen. 


\subsection{Vergelijking potentiële zij-instromers met een politieverwante opleiding en mensen met een politieopleiding}

De politieverwante opleidingsrichtingen $\mathrm{MBO}$ en $\mathrm{HBO}$ Openbare orde en veiligheid bevatten vanzelfsprekend ook de politieopleidingen op $\mathrm{MBO}$ - en $\mathrm{HBO}$-niveau die tegenwoordig door de Politieacademie worden verzorgd. Sinds een aantal jaren krijgt een aspirant-politiefunctionaris een arbeidscontract en volgt tegelijkertijd een politieopleiding. We gaan er dus van uit dat degenen die aangeven een politieopleiding te hebben gevolgd ook bij de politie werkzaam zijn of zijn geweest. De vragen "Hoe groot is die groep met een politieopleiding in vergelijking tot de groep met een politieverwante opleiding?" en "Is de groep met een politieopleiding vergelijkbaar met de groep met een politieverwante opleiding?" worden in deze paragraaf beantwoord met behulp van tabel 2.3.

In tabel 2.3 is te zien dat de potentiële beroepsbevolking in 2007-2008 ongeveer 33.000 mensen met een afgeronde politieopleiding bevatte. Dit is een behoorlijke toename ten opzichte van de jaren negentig die waarschijnlijk toe te schrijven is aan de wervingsinspanningen en de capaciteitsuitbreiding van de politieacademie vanaf begin 2000 waardoor elk jaar meer aspiranten konden worden begroet. 5 Dit betekent dat de verhouding tussen mensen met een politieverwante opleiding niet zijnde een politieopleiding en mensen mét een politieopleiding in de potentiële beroepsbevolking ongeveer 2 staat tot $\mathrm{I}$ is.

Wat betreft de ontwikkeling van de kenmerken geslacht, leeftijd, herkomst en opleidingsniveau in de potentiële beroepsbevolking met een politieopleiding zien we dat het aandeel vrouwen vooral de laatste jaren is gestegen tot $20 \%$ in $2007-2008$. De vergrijzing is in deze groep sterk aanwezig: het percentage 50-64 jarigen is gestegen van $24 \%$ in $1996-1997$ naar $38 \%$ in $2007-2008$ terwijl de groep 30-minners slechts lichtjes groeit. De gemiddelde leeftijd in deze groep is derhalve gestegen naar 44,I jaar in 2007-2008. Het aandeel allochtonen is redelijk stabiel rond de IO\% á I2\% waarbij een kleine verschuiving lijkt plaats te vinden van westerse naar niet-westerse allochtonen. Kijken we naar het opleidingsniveau dan valt op dat vooral in de laatste vier jaar een duidelijke verschuiving plaatsvindt van $\mathrm{MBO}$ naar $\mathrm{HBO}$-opleidingen.

5. Politieacademie (2008), Jaarverslag 2007, Politieacademie, Apeldoorn. 
Tabel 2.3

Ontwikkeling potentiële beroepsbevolking met een politieopleiding, 1996-2008

$\begin{array}{ccccccc}1996- & 1998- & 2000- & 2002- & 2005- & 2007- \\ 1997 & 1999 & 2001 & 2003 & 2006 & 2008\end{array}$

\begin{tabular}{|c|c|c|c|c|c|c|}
\hline $\begin{array}{l}\text { Potentiële beroepsbevolking met een politie- } \\
\text { opleiding (in personen) }\end{array}$ & 30.500 & 29.000 & 30.500 & 33.500 & 32.000 & 33.000 \\
\hline $\begin{array}{l}\text { als \% van de potentiële beroepsbevolking met een } \\
\text { politieverwante opleidingsrichting }\end{array}$ & 31 & 30 & 30 & 33 & 33 & 31 \\
\hline als \% van de potentiële beroepsbevolking & 0,29 & 0,27 & 0,28 & 0,31 & 0,29 & 0,30 \\
\hline & $\%$ & $\%$ & $\%$ & $\%$ & $\%$ & $\%$ \\
\hline \multicolumn{7}{|l|}{ Geslacht } \\
\hline Man & 86 & 87 & 85 & 89 & 84 & 80 \\
\hline Vrouw & 14 & 13 & 15 & 11 & 16 & 20 \\
\hline
\end{tabular}

$\begin{array}{lllllll}\text { Leeftijd } & & & & & \\ 15-29 \text { jaar } & 11 & 12 & 11 & 12 & 15 & 15 \\ 30-49 \text { jaar } & 64 & 60 & 58 & 56 & 48 & 47 \\ 50-64 \text { jaar } & 24 & 29 & 30 & 32 & 38 & 38 \\ \text { Gemiddelde leeftijd (in jaren) } & 42,3 & 43,0 & 43,7 & 43,7 & 44,4 & 44,1\end{array}$

\begin{tabular}{lrrrrrr} 
Herkomst & 90 & 88 & 92 & 92 & 90 & 88 \\
Autochtonen & 7 & 7 & 3 & 5 & 6 & 6 \\
Westerse Allochtonen & 3 & 6 & 5 & 4 & 4 & 6 \\
Niet-westerse Allochtonen & & & & & & \\
& & & & & & 77 \\
Opleidingsniveau & 97 & 95 & 94 & 93 & 83 & 17 \\
MBO Politie & 3 & 5 & 6 & 7 & 23 \\
HBO Politie & & & & & & \\
\hline
\end{tabular}

Bron: CBS (EBB)

Een vergelijking tussen de potentiële zij-instromers met een politieverwante opleiding (zie tabel 2.I) en de potentiële beroepsbevolking met een politieopleiding (zie tabel 2.3) geeft het volgende beeld:

- de potentiële zij-instromers zijn minder vaak van het vrouwelijk geslacht, hun aandeel is echter wel groeiende;

- de potentiële zij-instromers zijn jonger en het aandeel jongeren groeit licht;

- de potentiële zij-instromers zijn vaker van allochtone afkomst;

- de potentiële zij-instromers zijn minder vaak opgeleid op HBO-niveau.

Zetten we bovenstaande vergelijking af tegen de kenmerken van de potentiële beroepsbevolking (zie tabel B2.2 in de bijlage) en daarmee de kenmerken van een belangrijk deel van de maatschappij, dan zien we dat een succesvol wervingsbeleid in de groep potentiële zij-instromers met een politieverwante opleiding kan leiden tot een politie die een betere afspiegeling is van de maatschappij. 
Het arbeidsmarktpotentieel bestaat uit mensen die "een mogelijke interesse hebben in een executieve functie bij de politie, maar niet in een dergelijke functie werkzaam zijn" (zie pagina 5). Het aantal potentiële zij-instromers met een politieverwante opleiding bedroeg in 2007-2008 I05.500 personen (zie tabel 2.I). Hiervan zijn er 33.000 in het bezit van een politieopleiding en dus naar alle waarschijnlijkheid bij de politie werkzaam. Het arbeidsmarktpotentieel zou dan neerkomen op ongeveer 72.500 personen in 2007-2008. Echter, een deel van de potentiële zij-instromers met een politieverwante opleiding is niet beschikbaar voor de arbeidsmarkt: ongeveer $13 \%$ (zie tabel 2.2). Wanneer dit gegeven wordt meegenomen in de berekening van het arbeidspotentieel met een politieverwante opleiding, komen we uit op een omvang van ongeveer 63.000 personen.

\subsection{Ontwikkeling potentiële zij-instromers werkzaam in een politieverwant beroep}

Interesse voor een executieve politiefunctie kan niet alleen aan de gevolgde opleiding worden afgelezen, maar ook aan het huidige beroep. Vandaar dat de tweede groep van potentiële zij-instromers bestaat uit mensen die werkzaam zijn in een politieverwant beroep, maar niet in een executief politieberoep. Zij worden aangeduid met de term potentiële zij-instromers werkzaam in een politieverwant beroep. In deze paragraaf zal deze groep overigens nog wel de werkenden in een executief politieberoep bevatten. Pas wanneer in paragraaf 2.5 ook de werkenden in een executieve politiefunctie zijn besproken is het mogelijk om het arbeidspotentieel van deze groep te bepalen.

De potentiële zij-instromers werkzaam in een politieverwant beroep zijn op hun beurt een subgroep van de werkzame beroepsbevolking in tegenstelling tot de potentiële beroepsbevolking die het uitgangspunt vormde in de paragrafen 2.2 en 2.3. In tabel 2.4 is te zien dat deze groep in omvang is gegroeid naar iets meer dan 120.000 personen in 2007-2008. Verder is het aandeel vrouwen gegroeid tot ongeveer $20 \%$. Ook in deze groep zij-instromers slaat de vergrijzing toe, maar het blijft toch een relatief jonge groep: in alle onderzochte jaren is een derde jonger dan 30 jaar en het aandeel 50-64 jarigen bedraagt maximaal I6\%. Er is blijkbaar voldoende jonge aanwas. Verder is het aandeel personen van allochtone, met name niet-westerse, afkomst licht gestegen. Het opleidingsniveau van de potentiële zij-instromers werkzaam in een politieverwant beroep is omhoog gegaan: het aandeel mensen met een VMBO-opleiding is gedaald terwijl het aandeel hoger opgeleiden is toegenomen. 
Tabel 2.4

Ontwikkeling werkzame beroepsbevolking in een politieverwant beroep, 1996-2008

$\begin{array}{ccccccc}1996- & 1998- & 2000- & 2002- & 2005- & 2007- \\ 1997 & 1999 & 2001 & 2003 & 2006 & 2008\end{array}$

\begin{tabular}{lccccccc}
$\begin{array}{l}\text { Werkzame beroepsbevolking werkzaam in een } \\
\text { politie of politieverwant beroep (in personen) }\end{array}$ & 104.500 & 94.000 & 103.500 & 108.000 & 116.500 & 120.500 \\
\% van de werkzame beroepsbevolking & 1,66 & 1,40 & 1,48 & 1,54 & 1,66 & 1,64 \\
& & & & & & \\
& & $\%$ & $\%$ & $\%$ & $\%$ & $\%$ \\
\hline Geslacht & & & & & & \\
Man & 87 & 87 & 84 & 83 & 83 & 81 \\
Vrouw & 13 & 13 & 16 & 17 & 17 & 19
\end{tabular}

$\begin{array}{lclllll}\text { Leeftijd } & 34 & 33 & 33 & 33 & 33 & 33 \\ 15-29 \text { jaar } & 56 & 56 & 55 & 53 & 50 & 51 \\ 30-49 \text { jaar } & 9 & 11 & 13 & 15 & 16 & 16 \\ 50-64 \text { jaar } & 35,0 & 35,6 & 36,2 & 36,4 & 36,7 & 36,6 \\ \text { Gemiddelde leeftijd (in jaren) } & & & & & \end{array}$

$\begin{array}{lrrrrrr}\text { Herkomst } & & & & & \\ \text { Autochtonen } & 85 & 83 & 84 & 84 & 83 & 81 \\ \text { Westerse Allochtonen } & 8 & 8 & 8 & 7 & 7 & 8 \\ \text { Niet-westerse Allochtonen } & 7 & 9 & 8 & 8 & 10 & 10 \\ & & & & & & \\ \text { Opleidingsniveau } & & & & & & 22 \\ \text { VMBO } & 25 & 26 & 28 & 25 & 21 & 63 \\ \text { HAV0 + VW0 + MB0 } & 67 & 67 & 64 & 64 & 64 & 15 \\ \text { HBO + WO } & 7 & 7 & 8 & 10 & 14 & \end{array}$

In hoeverre is de hiervoor beschreven werkzame beroepsbevolking in een politieverwant beroep (zie tabel 2.4) vergelijkbaar met de totale werkzame beroepsbevolking (zie tabel B2.3 in de bijlage)? Een vergelijking tussen beide groepen laat zien dat de groep werkenden in een politieverwant beroep ten opzichte van de totale werkzame beroepsbevolking:

- $\quad$ veel minder vrouwen bevat (19\% t.o.v. $43 \%$ in 2007-2008);

- $\quad$ gemiddeld jonger is (36,6 t.o.v. 39,9 jaar in 2007-2008);

- een vergelijkbaar aandeel personen van allochtone afkomst bevat;

- minder vaak een hoger (HBO of WO) opleidingsniveau heeft. 


\subsection{Vergelijking politieverwant werkenden en werkenden bij de politie}

In hoeverre zijn de potentiële zij-instromers op basis van hun huidige baan in een politieverwant beroep (zie tabel 2.4 in paragraaf 2.4 ) vergelijkbaar met het degenen die werkzaam zijn in een executief politieberoep? In de EBB-data is het niet mogelijk om de politiefuncties te scheiden van de politieverwante functies. Daarom wordt hiervoor geput uit de Kerngegevens overheidspersoneel en de KOSMOS Kennisbank van het Ministerie van BZK.

Tabel 2.5

Ontwikkeling werkenden in een executief politieberoep, 1997-2008 ${ }^{6}$

$\begin{array}{lllllllll}1997 & 1998- & 2000- & 2002- & 2004 & 2005- & 2007- \\ & 1999 & 2001 & 2003 & & 2006 & 2008\end{array}$

$\begin{array}{llllllll}\begin{array}{l}\text { Werkenden in een executief } \\ \text { politieberoep (in personen) }\end{array} & 33.503 & 33.778 & 37.232 & 40.416 & 40.310 & 40.615 & 41.995\end{array}$

$\begin{array}{lcccccccc} & \% & \% & \% & \% & \% & \% & \% \\ \text { Geslacht } & & & & & & & & \\ \text { Man } & 85 & 84 & 82 & 80 & 79 & 78 & 76 \\ \text { Vrouw } & 15 & 16 & 18 & 20 & 21 & 22 & 24\end{array}$

$\begin{array}{llllllll}\text { Leeftijd } & 14 & 14 & 16 & 21 & 21 & 22 & 24 \\ 15-29 \text { jaar } & 72 & 70 & 65 & 60 & 58 & 56 & 51 \\ 30-49 \text { jaar } & 13 & 16 & 18 & 19 & 21 & 22 & 25 \\ 50-64 \text { jaar } & 13\end{array}$

Bron: BZK (Kerngegevens Overheidspersoneel, KOSMOS Kennisbank)

Tabel 2.5 laat zien dat het 'blauw' in omvang gegroeid is tussen 1997 en 2008. Hierbij moet wel opgemerkt worden dat de aspiranten pas vanaf 200 I worden opgenomen bij de werkenden van de politie. Dit verklaart mede de toename tussen 1998-1999 en 2000-200I. Daarnaast is het aandeel vrouwen fors toegenomen in die periode, van $15 \%$ in 1997 naar $24 \%$ in $2007-2008$. De ontwikkelingen in de leeftijdsopbouw zorgen ervoor dat het 'blauw' op twee verschillende manier van 'kleur' verandert. Aan de ene kant wordt de politie 'groener' door een toename van het aandeel jongeren: inmiddels is een kwart van de uitvoerende politiemensen jonger dan dertig jaar. Aan de andere kant kleurt de politie echter 'grijzer' door een toename van het aandeel ouderen: de 50 tot en met 64 jarigen maken ondertussen ook bijna een kwart van het executieve personeelsbestand uit. Een vergelijking tussen tabel 2.3 en 2.5 laat overigens iets opmerkelijks zien: het aantal mensen in de potentiële beroepsbevolking met een politieopleiding is in alle bestudeerde jaren lager dan het aantal werkenden in

6. Om de gegevens in deze tabel goed te kunnen vergelijken met voorgaande tabellen zijn op dezelfde manier tweejaargemiddelden berekend. Voor 1996 zijn geen gegevens beschikbaar. Ook zijn er geen gegevens beschikbaar over de herkomst en het opleidingsniveau van de werkenden bij de politie in een executieve functie. 
een executief politieberoep. Dit zou kunnen betekenen dat er mensen bij de politie werken die geen politieopleiding hebben gehad. Waarschijnlijker is echter dat een deel van de politieagenten (waarschijnlijk de oudere agenten) hun politieopleiding niet als een officiële opleiding ziet.

Wanneer we vervolgens de potentiële zij-instromers werkend in een politieverwant beroep (zie tabel 2.4) vergelijken met degenen die werkzaam zijn in een executief politieberoep (zie tabel 2.5), dan valt op dat onder de potentiële zij-instromers: ${ }^{7}$

- vrouwen ondervertegenwoordigd zijn (19\% t.o.v. 24\% in 2007-2008);

- $\quad$ het aandeel jongeren veel groter is (33\% t.o.v. $24 \%$ in 2007-2008);

- het aandeel ouderen veel lager is (I6\% t.o.v. $25 \%$ in $2007-2008$ );

De groep potentiële zij-instromers werkend in een politieverwant beroep bestaat in 2007-2008 uit 120.500 personen (zie tabel 2.4 in paragraaf 2.4). Uit tabel 2.5 blijkt dat er in dezelfde jaren gemiddeld 4I.995 personen aan het werk waren in een executieve politiefunctie. Dit betekent dat het arbeidsmarktpotentieel voor de politie (dat wil zeggen mensen die "een mogelijke interesse hebben in een executieve functie bij de politie, maar niet in een dergelijke functie werkzaam zijn”, zie pagina 5) van deze groep zij-instromers in 2007-2008 bestond uit ruim 78.000 personen.

\subsection{Samenvatting}

Een deel van het arbeidspotentieel voor de politie is afkomstig uit de potentiële beroepsbevolking die een politieverwante opleiding heeft gevolgd. Deze groep is qua omvang tamelijk constant in de periode 1996-2008 en bestaat voornamelijk uit mannen, hoewel het aandeel vrouwen groeiende is. De gemiddelde leeftijd in deze groep is slechts licht gestegen door een stijging van het aandeel I5-29 jarigen die de stijging in het aandeel 50-64 jaringen grotendeels compenseert. Deze groep kent een groeiend aandeel mensen van niet-westerse allochtone afkomst en bevat vooral mensen met een politieverwante opleiding op MBO-niveau.

De potentiële zij-instromers met een politieverwante opleiding zijn in vergelijking tot de potentiële beroepsbevolking vaker van het mannelijk geslacht, ouder, hoger opgeleid en vaker van autochtone afkomst. Vergelijken we het potentieel met een politieverwante opleiding met degenen die een politieopleiding gevolgd hebben, dan valt op dat het potentieel vaker man, jonger, iets vaker van (niet-westerse) allochtone afkomst en minder hoog opgeleid is. Het potentieel met een politieverwante opleiding is overigens niet allemaal arbeidspotentieel voor de politie. Ongeveer een derde

7. Door de korte doorlooptijd van dit onderzoek om op basis van de Kerngegevens Overheidspersoneel een vergelijking te maken tussen de herkomst en het opleidingsniveau van de potentiële zij-instromers werkend in een politieverwant beroep en de werkenden in een executieve politiefunctie. Een dergelijke vergelijking is mogelijk op basis van data verzameld voor het POMO-onderzoek (zie hoofdstuk 4). Door de korte doorlooptijd van dit onderzoek was het niet mogelijk. 
heeft namelijk een politieopleiding gevolgd en zal daarom al voor de politie werkzaam zijn. Ook is een deel van het potentieel (ongeveer 13\%) niet beschikbaar voor de arbeidsmarkt. Het daadwerkelijke arbeidspotentieel afkomstig uit het potentieel met een politieverwante opleiding wordt daarom geschat op ongeveer 63.000 personen in 2007-2008.

Een ander deel van het arbeidspotentieel voor de politie is afkomstig uit de groep werkenden in een politieverwant beroep. Deze groep is in omvang gegroeid in de periode I996-2008 en bestaat voornamelijk uit mannen al hoewel het aandeel vrouwen is gegroeid tot $20 \%$ in $2007-2008$. Ook is het, ondanks de toenemende vergrijzing, een relatief jonge groep: in 2007-2008 is slechts I6\% 50-64 jaar oud. Het aandeel nietwesterse allochtonen nam toe tot $10 \%$ in $2007-2008$ en het toch al hoge opleidingsniveau (twee derde heeft een opleiding op MBO-niveau) steeg verder door een toename van het aandeel HBO'ers en een afname van het aandeel VMBO'ers.

Het potentieel werkzaam in een politieverwant beroep is in vergelijking tot de werkzame beroepsbevolking vaker man, jonger en lager opgeleid. Waneer we het potentieel vergelijken met degenen die werken in een exectieve politiefunctie, dan zien we dat het potentieel relatief meer mannen bevat en gemiddeld jonger is. Overigens hoort niet al het potentieel werkzaam in een politieverwant beroep (ongeveer I20.000 personen in 2007-2008) tot het arbeidspotentieel voor de politie. Immers, ongeveer 42.00o personen werken al in een executieve politiebaan. Het daadwerkelijke arbeidspotentieel afkomstig uit het potentieel met een politieverwant beroep komt dus neer op ongeveer 78.000 personen in 2007-2008. 


\section{Het arbeidspotentieel voor de politie in de toekomst}

In dit hoofdstuk wordt beschreven hoe het arbeidspotentieel voor de politie zich in de komende vijf tot tien jaar zal ontwikkelen. Er wordt zowel naar de omvang als naar enkele achtergrondkenmerken van het toekomstig arbeidspotentieel gekeken. In de eerste paragraaf wordt specifiek naar het potentieel van relevante groepen toekomstige schoolverlaters gekeken. Daarna volgen beschrijvingen van het toekomstbeeld van het potentieel met een politieverwante opleiding (paragraaf 3.2) en het toekomstbeeld van het potentieel werkzaam in een politieverwant beroep (paragraaf 3.3). Tot slot volgt in paragraaf 3.4 een samenvatting van dit hoofdstuk.

\subsection{Toekomstig arbeidspotentieel van schoolverlaters}

Aan het begin van hoofdstuk 2 zijn in het arbeidspotentieel voor de politie drie groepen onderscheiden, namelijk de potentiële zij-instromers met een politieverwante opleiding, de potentiële zij-instromers werkzaam in een politieverwant beroep en de toekomstige schoolverlaters. In het vorige hoofdstuk is de historische ontwikkeling van de twee zij-instromer groepen uitgebreid beschreven en vergeleken met de degenen die een politieopleiding hebben gevolgd en/of bij de politie werken in een executieve functie. In de paragrafen 3.2 en 3.3 zal de toekomstige ontwikkeling van beide groepen zij-instromers besproken worden. In deze paragraaf, paragraaf 3.I, zal ingegaan worden op het toekomstig arbeidspotentieel dat wordt gevormd door de schoolverlaters die in de komende vijf jaar (tot 20I4) hun opleiding zullen afronden en zich zullen aanbieden op de arbeidsmarkt. Deze gegevens zijn afkomstig uit het Arbeidsmarktinformatiesysteem (AIS) van het ROA. Het AIS dient als basis voor de tweejaarlijkse ROA-publicatie "De arbeidsmarkt naar opleiding en beroep tot 2oxx".

\section{Afbakening voor de politie relevante groepen toekomstige schoolverlaters}

De politie vereist geen specifieke vooropleiding (qua richting) voor de verschillende politiefuncties. Aspiranten beginnen immers met een specifieke politieopleiding op het moment dat hun baan bij de politie aanvangt, de zogenaamde duale opleiding.

1. De meest recente publicatie is "De arbeidsmarkt naar opleiding en beroep tot 2014". 
Het gaat dan om initieel onderwijs dat voorbereidt op de uitoefening van het politievak op vijf niveaus, variërend van Assistent Politiemedewerker (MBO niveau 2) tot Politiekundige Master (HBO/WO-niveau). ${ }^{2} \mathrm{Zo}$ beschouwd zou iedereen met minimaal een VMBO-diploma, ongeacht de opleidingsrichting die in de komende vijf jaar de opleiding verlaat en zich op de arbeidsmarkt besluit aan te bieden, behoren tot de voor de politie relevante groep schoolverlaters. Echter, in hoofdstuk 2 is het arbeidspotentieel van de politie omschreven als "personen die een mogelijke interesse hebben in een executieve functie bij de politie, maar niet in een dergelijke functie werkzaam zijn" (zie pagina 5). Het is niet reëel te verwachten dat alle schoolverlaters deze interesse zullen hebben.

Om een meer realistische inschatting te maken welke toekomstige schoolverlaters mogelijk geïnteresseerd zijn in een executieve politiefunctie, zijn twee verschillende wegen bewandeld. De eerste weg behelst het achterhalen van de hoogst gevolgde vooropleiding van degenen die in 2007-2008 werkzaam waren in een politieverwant beroep. Dit zijn beroepen die vallen in één van de volgende beroepsgroepen: Aspirant politieagenten, soldaten en beveiligingshulpkrachten (in het vervolg Aspirant politieagenten genoemd), Politieagenten, onderofficieren en beveiligingsemployés (in het vervolg Politieagenten genoemd) en Politie-inspecteurs en officieren (in het vervolg Politie-inspecteurs genoemd). ${ }^{3}$ Het blijkt dat de vooropleiding van degenen in de laatstgenoemde beroepsgroep, Politie-inspecteurs en officieren, divers is. Tussen de vooropleidingen van degenen werkzaam in de beroepsgroepen Aspirant politieagenten en Politieagenten zijn wél een aantal veel voorkomende vooropleidingen te onderscheiden. Daarnaast is er veel overlap tussen de vooropleidingen in deze beide beroepsgroepen. In tabel 3.I wordt een totaaloverzicht gegeven van de vooropleidingen van degenen die werken in de beroepsgroep Aspirant politieagenten of in de beroepsgroep Politieagenten.

Een kwart van de werkenden blijkt een specifieke beroepsopleiding te hebben gevolgd, namelijk een MBO-opleiding in de richting openbare orde en veiligheid. $23 \%$ heeft daarentegen een diploma van een algemene middelbare opleiding behaald alvorens "bij de politie te gaan": I4\% heeft een HAVO- of een VWO-diploma en $9 \%$ heeft een diploma VMBO theoretische leerweg op zak. Nog eens $6 \%$ heeft een opleiding van de politieverwante opleidingsrichtingen op VMBO-niveau (beveiliging) of HBO (openbare orde en veiligheid) gevolgd. Hoewel een aantal opleidingsrichtingen er duidelijk uitspringen, moet hier de opmerking worden gemakkt dat een derde van de werkenden in de politieberoepsgroepen een opleiding uit de categorie "anders" heeft gevolgd.

De tweede weg die is bewandeld om de relevante groepen schoolverlaters te definieren, is door te kijken naar de vooropleiding van degenen die recentelijk zijn ingestroomd in een executieve politiefunctie. Hiervoor is gebruik gemaakt van gegevens uit het Mobiliteitsonderzoek van het Ministerie van BZK van de metingen uitgevoerd

2. Politieacademie (2008), Jaarverslag 2007 Politieacademie, Apeldoorn.

3. Zie B2.I in de bijlage voor een overzicht van alle beroepen die onder deze drie beroepsgroepen vallen. 
in 2004 en 2008. ${ }^{4}$ Dit betreft personen die in de jaren 2003 en 2007 begonnen zijn in een executieve politiefunctie.

\section{Tabel 3.1}

Type vooropleiding van werkenden in de beroepsgroep Aspirant politieagenten of Politieagenten (\%), 2007-2008

\begin{tabular}{lc}
\hline MBO openbare orde en veiligheid & $2007-2008$ \\
\hline HAVO/VWO & 24 \\
VMBO theoretische leerweg & 14 \\
\hline MBO administratie en logistiek & 9 \\
\hline MBO handel & 4 \\
\hline HBO openbare orde en veiligheid & 3 \\
\hline MBO elektrotechniek & 3 \\
\hline VMBO beveiliging & 3 \\
\hline VMBO administratie, handel en mode & 3 \\
\hline MBO sociaal-pedagogisch en welzijn & 2 \\
\hline Andere opleidingstypen & 1 \\
\hline Totaal & 33 \\
Bron: ROA (AIS) & 100 \\
\hline
\end{tabular}

In tabel 3.2 is te zien dat, net als in de voorgaande tabel 3.I, een flink deel van de recente politieinstromers een algemene opleiding had (HAVO/VWO $19 \%-16 \%$ ). Ook heeft $29 \%-23 \%$ een VMBO tl of andere VMBO-opleiding gevolgd. Ook in tabel 3.2 komt de specifieke beroepsopleiding openbare orde en veiligheid/beveiliging op MBO- of HBO-niveau regelmatig voor (7\% - 13\%). Een opvallend verschil tussen beide tabellen is dat de opleidingsrichting economisch, administratief, commercieel onder de recente politieinstromers veel vaker voorkomt dan onder alle werkenden in de politieverwante beroepsgroepen Aspirant politieagenten en Politieagenten. Dit verschil kan worden verklaard door het feit dat tabel 3.2 ook de politiefuncties op $\mathrm{HBO} / \mathrm{WO}$ niveau bevat en tabel 3.I niet. Eerder is aangeven, dat de vooropleidingen van degenen in de beroepsgroep Politieinspecteurs te divers zijn om weer te geven in tabel 3.I. Het is mogelijk dat juist onder de werkenden in de hogere politiefuncties een opleiding uit de richting economisch, administratief, commercieel meer voorkomt.

Een andere verklaring kan zijn dat tabel 3.I is gebaseerd op iedereen die in 2007-2008 werkzaam was in de politieverwant beroepsgroepen, terwijl tabel 3.2 alleen de recente instromers bekijkt. Het is goed mogelijk dat recente instromers vaker een economische, administratieve of commerciële opleiding hebben gevolgd dan het zittende politiepersoneel.

4. Deze data is hoofdzakelijk gebruikt om in hoofdstuk 4 de pullfactoren van het werken bij de politie te bepalen. Meer informatie over deze data is om die reden in hoofdstuk 4 te vinden. In de meting van 2006 is de instromers niet gevraagd naar de opleidingsrichting van hun vooropleiding, vandaar dat de gegevens uit die meting hier niet gebruikt zijn. 
Tabel 3.2

Instroom in executieve politiefuncties naar hoogst voltooide opleidingsniveau en -richting, 2003 en 2007

\begin{tabular}{lcc} 
& 2003 & 2007 \\
& $\%$ & $\%$ \\
\hline MAVO, VMBO-tl of ten hoogste 3 jaar HAVO, VWO (inclusief Basisonderwijs en LBO) & & \\
HAV0, VWO & 29 & 23 \\
Middelbaar beroepsonderwijs & 19 & 16 \\
Hoger beroepsonderwijs en wetenschappelijk onderwijs & 38 & 39
\end{tabular}

\section{Opleidingsrichtingen van $\mathrm{MBO}, \mathrm{HBO}$ en WO:}

Openbare orde en veiligheid, beveiliging

Sociale richtingen, maatschappelijk werk, welzijn

Techniek, wis- en natuurwetenschappen

Rechten, bestuurskunde

Lerarenopleiding, onderwijskunde

Persoonlijke verzorging, voeding, horeca*

Medisch, paramedisch, gezondheidszorg

Agrarisch, natuur en milieu

Letteren, kunst en cultuur

Transport, vervoer en logistiek

Informatica, ICT, automatisering

Bouwkunde, weg- en waterbouw

Anders*

Totaal opleidingsrichtingen op MBO, HBO en WO niveau

23

- 3

Deze antwoordcategorieën ontbraken in de vragenlijst voor de instromers van 2003. Bron: BZK (POMO)

De analyses op basis van beide tabellen komen voldoende overeen om van een betrouwbaar beeld te spreken wat betreft de relevante vooropleidingen voor een executieve politiefunctie. Omdat de indeling in opleidingsrichtingen op basis van tabel 3.I het mogelijk maakt om prognoses te maken over schoolverlaters van bepaalde opleidingsrichtingen in de toekomst, wordt deze indeling gehanteerd in het vervolg van dit hoofdstuk.

\section{Omvang van relevante groepen toekomstige schoolverlaters tot 2014}

In de vorige subparagraaf is bepaald welke groepen schoolverlaters (naar opleidingsniveau en opleidingsrichting) mogelijk relevant zijn voor het arbeidspotentieel van de politie. In deze subparagraaf wordt eerst een schatting gemaakt van de omvang van deze groepen in de komende vijf jaar. Als uitgangspunt voor deze schatting dient de verwachte instroom van schoolverlaters op de arbeidsmarkt tot 2014 in de relevante opleidingstypen, uitgezonderd de categorie "Andere opleidingstypen". De verwachte 
instroom van schoolverlaters per relevant opleidingstype staat vermeld in kolom A van tabel 3.3. Vervolgens is berekend welk deel van de werkzame beroepsbevolking per opleidingstype in 2007-2008 werkzaam was in een politieverwante beroepsgroep (Aspirant politieagent, Politieagent of Politie-inspecteur). Deze percentages zijn weergegeven in kolom B van tabel 3.3. Verder nemen we aan dat de interesse voor een politieverwant beroep per opleidingstype niet zal wijzigen in de komende jaren. Met behulp van deze aanname is het mogelijk om de verwachte instroom van schoolverlaters per relevant opleidingstype in een politieverwant beroep te bepalen. Deze instroom is opgenomen in kolom C. Uit deze kolom blijkt dat het potentieel van de toekomstige schoolverlaters in de komende vijf jaar wordt geschat op ongeveer I6.000 schoolverlaters. Zij zijn hoofdzakelijk afkomstig van de opleidingsrichtingen $\mathrm{MBO}$ openbare orde en veiligheid, HAVO, VWO en VMBO (tl). Dit aantal van I6.00o schoolverlaters mag gezien worden als een onderschatting van het daadwerkelijke potentieel. Immers, in tabel 3.I is te zien dat een derde van alle werkenden in een politieverwant beroep een andere opleiding heeft gevolgd dan die opgenomen zijn in tabel 3.3 .

Tabel 3.3

Berekening verwachte instroom van schoolverlaters in een politieverwant beroep tot 2014

$\begin{array}{llll} & \text { Kolom A } & \text { Kolom B } & \text { Kolom C } \\ & \text { Verwachte instroom van } & \text { \% van alle werkenden } & \text { Verwachte instroom van } \\ \text { schoolverlaters op de } & \text { met dit opleidingstype } & \text { schoolverlaters in een } \\ \text { Opleidingstype } & \text { arbeidsmarkt tot 2014 } & \text { dat in (2007-2008) in een } & \text { politieverwant beroep } \\ & & \text { politieverwant beroep } & \text { tot 2014 } \\ & & \text { werkzaam was } & \end{array}$

\begin{tabular}{lrrr|}
\hline VMB0 theoretische leerweg & 47.100 & 2,1 & 1.007 \\
\hline VMBO administratie, handel en mode & 26.900 & 1,8 & 483 \\
\hline VMBO beveiliging & 2.100 & 42,8 & 899 \\
\hline HAVO/VWO & 133.300 & 2,4 & 3.231 \\
\hline MBO sociaal-pedagogisch en welzijn & 57.900 & 1,1 & 653 \\
\hline MBO administratie en logistiek & 36.500 & 1,4 & 496 \\
\hline MBO handel & 49.000 & 1,9 & 922 \\
\hline MBO elektrotechniek & 18.200 & 1,9 & 345 \\
\hline MBO openbare orde en veiligheid & 19.400 & 38,5 & 7.470 \\
\hline HBO openbare orde en veiligheid & 1.300 & 36,3 & 471 \\
\hline Totaal & 391.700 & & 15.979 \\
Bron: ROA (AIS) & & &
\end{tabular}

In paragraaf 2.5 is beschreven dat in 2007-2008 gemiddeld 120.500 personen werkzaam waren in een politieverwante beroepsgroep. Daarvan werkten er gemiddeld ongeveer 42.000 personen in een executieve politiefunctie. Dit komt overeen met $35 \%$. Een analyse van deze verhoudingen in de periode 1997-2006 laat zien dat dit percentage schommelt tussen $33 \%$ en $35 \%$. Wanneer deze trend zich ook doorzet in de toekomst, dan zou dit betekenen dat ongeveer een derde van de I6.000 schoolverlaters 
die instromen in een politieverwante beroepsgroep, daadwerkelijk voor een executief politieberoep kiezen.

\section{Omvang van relevante groepen toekomstige schoolverlaters tot 2020}

Uit de vorige subparagrafen is gebleken dat de schoolverlaters die relevant zijn voor de politie doorgaans een MBO-, een HAVO/VWO- of een VMBO (tl)-diploma hebben. Om te zien hoe deze groepen zich na 2014 ontwikkelen, wordt gebruik gemaakt van de referentieramingen van het Ministerie van Onderwijs, Cultuur en Wetenschap (OCW).5 Deze ramingen geven per opleidingsniveau aan hoe deze zich in omvang en samenstelling zullen ontwikkelen tot 2020. Zo blijft het aantal MBO'ers uit de beroepsopleidende leerweg (bol) tussen 2010 en 2020 vrijwel constant op 60.000 gediplomeerden per jaar. Iets meer dan de helft van deze gediplomeerden biedt zich aan op de arbeidsmarkt, de anderen gaan naar het $\mathrm{HBO}$ of naar een MBO-bbl-opleiding. De uitstroom uit het $\mathrm{MBO}$ bbl neemt tussen 2010 en 2020 af. Deze daling komt echter vrijwel geheel voor rekening van de ongediplomeerden, het aantal gediplomeerden dat jaarlijks het MBO-bbl verlaat blijft constant op ongeveer 16.000 personen per jaar. Deze bbl-gediplomeerden bieden zich vrijwel allemaal aan op de arbeidsmarkt.

\section{Figuur 3.1}

Uitstroom MBO-opleidingen naar beroepsopleidende leerweg (bol) en beroepsbegeleidende leerweg (bbl), 1990-2020
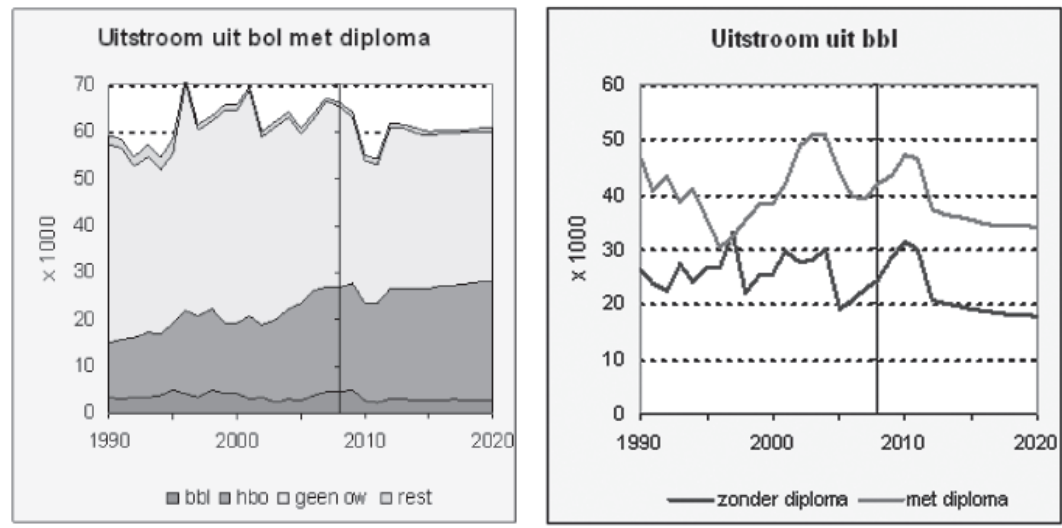

Bron: Ministerie van Onderwijs, Cultuur en Wetenschap, Referentieraming 2009, Den Haag (interne publicatie), pp. 27-28.

In de komende jaren (tot 2020) wordt een groei verwacht van het aantal HAVO- en VWO-gediplomeerden: het aantal HAVO-gediplomeerden zal toenemen van 4I.000 per jaar in 2010 naar 45.000 in 2020 en het aantal VWO-gediplomeerden stijgt van 35.000 in 2010 naar 40.000 in 2020 . Van deze gediplomeerden zullen zich 4.000

5. Ministerie van Onderwijs, Cultuur en Wetenschap, Referentieraming 2009, Den Haag (interne publicatie). 
HAVO-gediplomeerden en 5.000 VWO-gediplomeerden jaarlijks gaan aanbieden op de arbeidsmarkt. Het VMBO levert traditioneel de meeste gediplomeerden, maar dit aantal zal in de komende jaren afnemen van 95.000 gediplomeerden per jaar in 2010 tot 80.000 om 2020. Het aantal VMBO-gediplomeerden dat zich aanbiedt op de arbeidsmarkt neemt tussen 2010 en 2020 ook drastisch af. Het lijkt er dus op dat het arbeidspotentieel voor de politie op de langere termijn vooral onder HAVO/VWO- en $\mathrm{MBO}$-gediplomeerden in plaats van VMBO-gediplomeerden moet worden gezocht.

\subsection{Toekomstig arbeidspotentieel van potentiële zij-instromers met een politieverwante opleiding}

In deze en de volgende paragraaf wordt een beeld geschetst van het toekomstig arbeidspotentieel van de potentiële zij-instromers met een politieverwante opleiding respectievelijk het arbeidspotentieel van de potentiële zij-instromers werkend in een politieverwant beroep. De toekomstige ontwikkeling van beide groepen wordt zeer waarschijnlijk beïnvloed door ontwikkelingen in de onderliggende Nederlandse bevolking van 15 tot 65 jarigen. ${ }^{6}$ In lijn met de aspecten die tot nu toe in dit rapport besproken zijn, worden de volgende vier ontwikkelingen van de bevolking van is tot 65 jaar besproken: omvang, geslacht, leeftijd en herkomst.

Tot 20 II wordt nog een lichte groei tot II,I miljoen mensen in de leeftijd van is tot 65 jaar verwacht. Vanaf 2012 neemt deze groep echter in omvang af tot ruim Io,9 miljoen personen in 2019 (zie tabel 3.4). Dit hoeft echter niet te betekenen dat zich ook minder mensen zullen aanbieden op de arbeidsmarkt, omdat het daadwerkelijke aanbod ook bepaald wordt door de arbeidsparticipatie. Deze arbeidsparticipatie zal in de komende jaren toenemen van $75 \%$ in 2007 naar $77 \%$ in 2015 . Deze toename komt voor een belangrijk deel voor rekening van ouderen en vrouwen. ${ }^{7}$ Het aandeel mannen en vrouwen blijft de komende jaren gelijk verdeeld. De leeftijdsopbouw van de bevolking in de werkzame leeftijd wordt zowel groener als grijzer: zowel het aandeel I5- tot 30-jarigen als het aandeel 50- tot 65-jarigen stijgt. In 2019 zal naar verwachting $29 \%$ van de bevolking tussen de 15 en 30 jaar oud zijn en $33 \%$ heeft een leeftijd tussen de 50 en 65 jaar. Tot slot zal ook het aandeel personen van niet-westerse allochtone afkomst stijgen waardoor in 2019 ongeveer een kwart van de Nederlandse bevolking van allochtone afkomst zal zijn.

6. In het licht van de geplande verhoging in de AOW leeftijd, zou deze groep uitgebreid kunnen worden naar $15-67$ jarigen. Echter, gezien de termijn waarop deze verhoging daadwerkelijk plaats zal vinden, zal dit naar verwachting geen invloed hebben op deze prognoses.

7. CPB, Memorandum 225: Arbeidsaanbod en gewerkte uren tot 2050, 23 april 2009. NB: het CPB berekent de arbeidsparticipatie voor de bevolking van $20-65$ jaar. Deze groep bevat dus minder mensen dan de in dit rapport gehanteerde groep van $15-65$ jaar. 


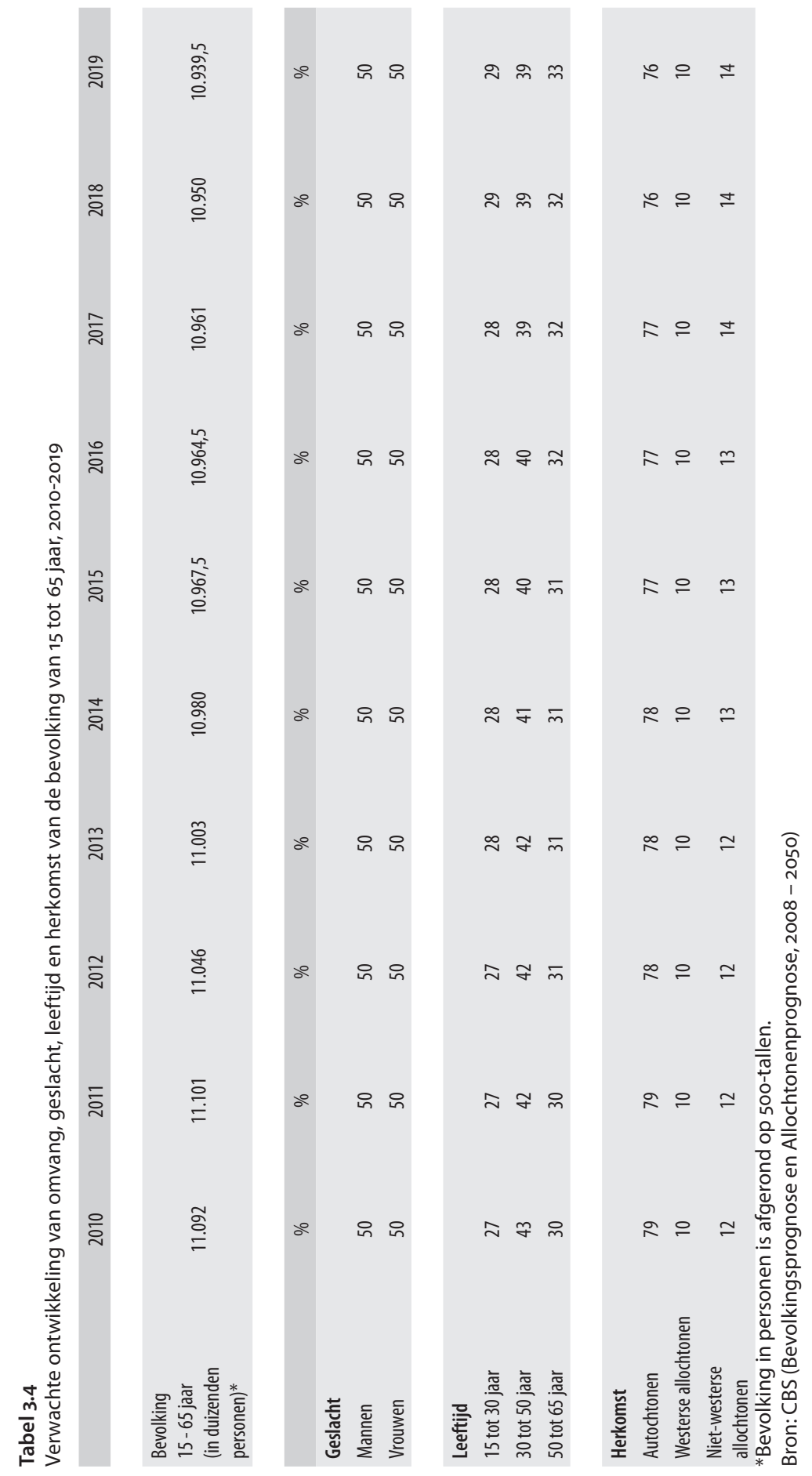


In paragraaf 2.2 is onder andere besproken hoe het potentieel met een politieverwante opleiding zich tussen 1996 en 2008 heeft ontwikkeld. Deze ontwikkeling kenmerkt zich om te beginnen door een geringe groei van de omvang. Daarnaast hebben we een toename gezien van het aandeel vrouwen, het aandeel I5-29 jarigen en het aandeel 50-64 jarigen. Ook nam het aandeel niet-westerse allochtonen toe, maar nam het aandeel westerse allochtonen af waardoor het totale aandeel allochtonen ongeveer gelijk bleef. Er kwamen meer mensen met een hogere opleiding, maar ook het aandeel VMBO'ers nam toe. Wanneer de verwachte ontwikkelingen in de bevolking van Is tot 65 jaar worden gecombineerd met de historische ontwikkeling van de politieverwant opgeleide zij-instromers, levert dit het volgende toekomstbeeld op voor de politieverwant opgeleide zij-instromers:

\section{Omvang}

Om te beginnen zal de omvang van dit potentieel (IO5.500 personen in 2007-2008) tot 20 II ongeveer gelijk blijven, aangezien de omvang van deze groep in de afgelopen jaren nauwelijks veranderd is. Vanaf 2012 zal deze groep enigszins in omvang afnemen, rekening houdend met de geschetste afname van de bevolking van 15 tot 65 jaar vanaf 2012.

\section{Geslacht}

Naar verwachting zal het aandeel vrouwen in het potentieel met een politieverwante opleiding verder toenemen. Enerzijds omdat deze toename zich in de afgelopen jaren al aftekende, anderzijds omdat het huidige aandeel van I4\% (zie tabel 2.I) nog altijd ver onder het (huidige en toekomstige) aandeel vrouwen in de totale bevolking van Is tot 65 jaar ligt $(50 \%)$. Bovendien zullen de vrouwen in deze groep zich ook meer op de arbeidsmarkt gaan aanbieden gelet op de eerder genoemde verwachte stijging in de arbeidsparticipatie onder vrouwen.

\section{Leeftijd}

De ingezette trend van een groter aandeel 15 - tot 30-jarigen en een groter aandeel 50tot 65-jarigen onder de politieverwant opgeleide potentiële zij-instromers zal zich naar verwachting doorzetten in de komende tien jaar, aangezien de bevolking van 15 tot 65 jaar zich op dezelfde manier zal ontwikkelen. Echter, het aandeel 15 - tot 30-jarigen in de bevolking ligt op een veel hoger niveau dan in het huidige potentieel met een politieverwante opleiding. Hierdoor is het mogelijk dat het aandeel I5- tot 30-jarigen ook in dit potentieel harder zal groeien en derhalve ook het arbeidsmarktaanbod uit deze groep. Deze groei van het arbeidsmarktaanbod kan echter afgeremd worden doordat jongeren uit deze leeftijdsgroep een (vervolg)opleiding volgen en zich daardoor (nog) niet aanbieden op de arbeidsmarkt. Zo wordt bijvoorbeeld verwacht dat VMBO'ers zich steeds minder vaak zullen aanbieden op de arbeidsmarkt, omdat zij doorstromen naar een vervolgopleiding. ${ }^{8}$

8. Ministerie van Onderwijs, Cultuur en Wetenschap, Referentieraming 2009, Den Haag (interne publicatie). 


\section{Herkomst}

Het aandeel van met name niet-westerse allochtonen is in de afgelopen jaren toegenomen. Gezien de verwachte demografische ontwikkelingen in de bevolking van is tot 65 jaar, zal dit aandeel in de toekomst ook onder het potentieel met een politieverwante opleiding toenemen.

\subsection{Toekomstig arbeidspotentieel van potentiële zij-instromers werkend in een politieverwant beroep}

De historische ontwikkeling van het arbeidspotentieel gevormd door de potentiële zij-instromers werkend in een politieverwant beroep is beschreven in paragraaf 2.4. Kort samengevat kenmerkt de ontwikkeling van dit potentieel zich door een toename in omvang tot gemiddeld $\mathbf{2} 20.500$ personen in 2007-2008, een toename van het aandeel vrouwen en een toename van het aandeel 50- tot 65-jarigen terwijl het aandeel jongeren constant een derde bedroeg. Ook nam het aandeel niet-westerse allochtonen licht toe en verdubbelde het aandeel personen met een hogere opleiding tot $15 \%$, terwijl het aandeel VMBO-opgeleiden licht daalde tot iets meer dan $20 \%$.

Wanneer we deze historische ontwikkelingen combineren met de verwachte toekomstige ontwikkelingen in de bevolking van I5 tot 65 jaar (zie tabel 3.4 in paragraaf 3.2), dan ontstaat hieruit het volgende toekomstbeeld van het potentieel werkend in een politieverwant beroep:

\section{Omvang}

De historische groei in de omvang van deze groep zij-instromers zal waarschijnlijk nog wel enkele jaren doorzetten, maar daarna vermoedelijk tot een halt komen en misschien zelfs omslaan in lichte krimp als gevolg van de verwachte afname in de bevolking van is tot 65 jaar.

\section{Geslacht}

De toename van het aandeel vrouwen in deze groep zal naar verwachting ook in de toekomst doorzetten, omdat dit aandeel met $19 \%$ in 2007-2008 nog ruim onder het aandeel vrouwen van de (huidige en toekomstige) bevolking ligt. Ook de eerder genoemde verwachte toename in de arbeidsparticipatie van vrouwen draagt aan deze ontwikkeling bij.

\section{Leeftijd}

Het aandeel jongeren in de leeftijd van 15 tot 30 jaar is al tien vrijwel onveranderd gebleven binnen deze groep potentiële zij-instromers. De verwachting is dat dit aandeel ook de komende tien jaar vrijwel ongewijzigd zal blijven, mede gezien het feit dat dit aandeel jongeren nu al beduidend hoger ligt dan het aandeel jongeren in de bevolking van 15 tot 65 jaar. Het is echter ook mogelijk dat het aandeel jongeren in deze groep zij-instromers zal toenemen omdat het hoge huidige aandeel jongeren 
aangeeft dat dit voor jongeren een aantrekkelijke beroepsgroep is om in te werken. Eén en ander hangt echter ook af van de ontwikkeling van het aandeel 30- tot 50- en 50- tot 65-jarigen. Het aandeel 50- tot 65-jarigen in het potentieel werkend in een politieverwant beroep zal in de komende jaren vermoedelijk toenemen. Dit heeft enerzijds te maken met de verwachte demografische ontwikkelingen in de bevolking van I5 tot 65 jaar (zie tabel 3.4) en anderzijds met de maatregelen die het langer doorwerken stimuleren.

\section{Herkomst}

De potentiële zij-instromers werkend in een politieverwant beroep zijn in de afgelopen jaren steeds vaker van niet-westerse allochtone afkomst geweest. Gelet op de verwachte toename van het aandeel niet-westerse allochtonen in de Nederlandse bevolking en het feit dat dit aandeel hoger is dan onder de huidige zij-instromers, zullen deze zij-instromers in de toekomst steeds vaker een met name niet-westerse allochtone afkomst hebben.

\subsection{Samenvatting}

De meest relevante groepen schoolverlaters voor de politie zijn de MBO'ers openbare orde en veiligheid, HAVO/VWO-gediplomeerden en VMBO'ers van de theoretische leerweg. Echter, ook schoolverlaters met een andere VMBO, MBO of $\mathrm{HBO}$ achtergrond kunnen interessant zijn voor de politie gezien het bonte palet aan vooropleidingen van de huidige generatie werkenden bij de politie en de recente instromers. Naar verwachting zullen tot 2014 in totaal minstens 16.000 schoolverlaters aan de slag gaan in een politieverwant beroep. Wanneer trends uit het verleden worden doorgetrokken, zal hiervan een derde voor een executieve functie bij de politie kiezen. Op de langere termijn (tot 2020) moet men er bij wervingsinspanningen rekening mee houden dat het arbeidsmarktaanbod van VMBO'ers zal dalen, dat van scholieren met een HAVO- of VWO-diploma zal toenemen en dat van MBO-gediplomeerden (bol en bbl) gelijk zal blijven.

Naar verwachting zal de omvang en de samenstelling van het potentieel met een politieverwante opleiding en het potentieel werkzaam in een politieverwant beroep worden beïnvloed door de toekomstige ontwikkelingen in de bevolking van 15 - tot 65-jarigen. Samengevat ontwikkelt de bevolking van I5 tot 65 jaar zich tot 2020 als volgt: een lichte groei tot 20II, daarna krimp, de verdeling man-vrouw blijft 50\%-50\%, een lichte groei van zowel het aandeel jongeren ( 15 tot 30 jaar), het aandeel ouderen ( 50 tot 65 jaar) en het aandeel niet-westerse allochtonen. Daarnaast wordt een toename van de arbeidsparticipatie verwacht, voornamelijk onder vrouwen en ouderen.

Beide groepen potentieel zullen vanaf 20 II waarschijnlijk in omvang krimpen, het potentieel werkend in een politieverwant beroep zal tot die tijd waarschijnlijk nog licht toenemen. Het aandeel vrouwen in beide groepen zal toenemen door een combi- 
natie van de al ingezette trend van een toenemend aandeel vrouwen en de verwachte stijging in de arbeidsparticipatie van vrouwen. Het aandeel jongeren zal vermoedelijk toenemen in de groep potentieel met een politieverwante opleiding en gelijk blijven in de groep potentieel werkend in een politieverwant beroep. Het aandeel ouderen neemt in beide groepen toe door de vergrijzing van de bevolking en de verwachte stijging in de arbeidsparticipatie van ouderen. Tot slot zal ook in beide groepen het aandeel niet-westerse allochtonen licht toenemen. 


\section{Waarom (niet) werken bij de politie: pull- en pushfactoren van een executieve politiefunctie}

In dit hoofdstuk worden zowel de aantrekkelijke kanten (pullfactoren) als de minder aantrekkelijke kanten (pushfactoren) van het werken in een executieve politiefunctie beschreven aan de hand van analyses van instroom-en uitstroomgegevens uit het Mobiliteitsonderzoek van het Ministerie van BZK. De eerste paragraaf bevat een beschrijving van de gebruikte databestanden. Vervolgens worden in paragraaf 4.2 de pullfactoren en in paragraaf 4.3 de pushfactoren besproken. Een samenvatting van dit hoofdstuk is te vinden in paragraaf 4.4 .

\subsection{Mobiliteitsonderzoek: gegevens over instroom en uitstroom}

In de voorgaande hoofdstukken is uitgebreid stilgestaan bij de omvang en de aard van het arbeidspotentieel in de afgelopen jaren en hoe dit arbeidspotentieel zich zal ontwikkelen in de toekomst. Om optimaal gebruik te kunnen maken van dit potentieel is het van belang inzicht te krijgen in de redenen die mensen hebben om bij de politie in een executieve functie te willen werken of om een dergelijke functie juist te verlaten. Met andere woorden, wat makkt een executieve politiefunctie aantrekkelijk en wat ervaart men als onaantrekkelijk aan een dergelijke functie? De antwoorden op deze vragen kunnen aanknopingspunten bieden voor beleidsmaatregelen die de instroom bij de politie kunnen vergroten en/of de uitstroom kunnen tegengaan. Door het nemen van krachtige beleidsmaatregelen kunnen de eerder geschetste kwantitatieve ontwikkelingen van het arbeidspotentieel worden beïnvloed. De maatregelen kunnen ertoe leiden dat het beschikbare arbeidspotentieel beter wordt benut en langer wordt behouden voor de politie.

De aantrekkelijke en de onaantrekkelijke kanten van een executieve politiefunctie worden in dit hoofdstuk aangeduid met pullfactoren respectievelijk pushfactoren. Deze factoren worden geanalyseerd op basis van data die door het Ministerie van BZK is verzameld in het kader van het Mobiliteitsonderzoek. In dit Mobiliteitsonderzoek is een representatieve steekproef getrokken van zowel het instromend als uitstromend personeel in alle overheidssectoren De deelnemers worden bevraagd over het hoe en 
waarom van hun instroom cq. uitstroom. Dit Mobiliteitsonderzoek is onderdeel van het Personeels- en Mobiliteitsonderzoek (POMO) dat sinds 1999 elke twee jaar wordt gehouden onder het overheidspersoneel. Voor de analyses in dit hoofdstuk wordt gebruik gemaakt van de originele databestanden van de drie meest recente metingen uitgevoerd in 2004, 2006 en 2008. Deze metingen hebben betrekking op overheidspersoneel dat in het jaar voorafgaand aan de meting is in- dan wel uitgestroomd. ${ }^{\mathrm{I}} \mathrm{De}$ voor dit hoofdstuk gebruikte in- en uitstroomgegevens hebben derhalve betrekking op overheidspersoneel dat in de jaren 2003, 2005 en 2007 is in- dan wel uitgestroomd in een overheidsfunctie. In tabel 4.I is te zien hoe de totale in- en uitstroom (van executief en administratief/technisch personeel samen) in de politiesector zich verhoudt tot die van de totale overheid. De instroom maar vooral de uitstroom (als \% van het zittend personeel) is bij de politie aanmerkelijk lager dan bij de overheid als geheel.

\section{Tabel 4.1}

Zittend personeel ${ }^{2}$, instroom en uitstroom (in personen), instroom en uitstroom als $\%$ van het zittend personeel bij overheid en politie, 2003-2007

2003

\section{Overheid}

Zittend personeel

Instroom

Uitstroom

Instroom als \% van zittend personeel

Uitstroom als \% van zittend personeel
857.651

89.195

75.081

10,4

8,8

2005

2007

\section{Politie (executief én administratief/technisch)}

Zittend personeel

54.623

53.943

56.714

Instroom

3.131

4.085

5.800

Uitstroom

2.851

3.137

3.554

Instroom als \% van zittend personeel

5,7

7,6

10,2

Uitstroom als \% van zittend personeel

5,2

5,8

Bron: Ministerie van Binnenlandse Zaken en Koninkrijksrelaties (2005), Personeels- en Mobiliteitsonderzoek Overheidspersoneel 2003-2004, Den Haag.

Ministerie van Binnenlandse Zaken en Koninkrijksrelaties (2007), Personeels- en Mobiliteitsonderzoek Overheidspersoneel 2006, Den Haag.

Ministerie van Binnenlandse Zaken en Koninkrijksrelaties (2008), Quickscan Personeels- en Mobiliteitsonderzoek 2008, Den Haag.

I. In dit hoofdstuk wordt daar waar dit relevant is, extra informatie gegeven over deze data en het onderzoek. Zie voor een complete beschrijving van de gebruikte POMO-onderzoeken:

Ministerie van Binnenlandse Zaken en Koninkrijksrelaties (2005), Personeels- en Mobiliteitsonderzoek Overheidspersoneel 2003-2004, Den Haag.

Ministerie van Binnenlandse Zaken en Koninkrijksrelaties (2007), Personeels- en Mobiliteitsonderzoek Overheidspersoneel 2006, Den Haag.

Ministerie van Binnenlandse Zaken en Koninkrijksrelaties (2008), Quickscan Personeels- en Mobiliteitsonderzoek 2008, Den Haag.

2. Zittend personeel betreft personeel dat gedurende een kalenderjaar in dienst is gebleven van dezelfde overheidswerkgever. Zie paragraaf 4.2 en 4.3 voor definities instroom en uitstroom. 


\subsection{Pullfactoren van een executieve politiefunctie}

\section{Definitie en afbakening relevante groep instromers}

In het Mobiliteitsonderzoek wordt iemand als een instromer aangeduid wanneer hij of zij "in een kalenderjaar in dienst getreden is [.....] bij een overheidswerkgever [....], ongeacht de herkomst (opleiding, wachtgeld, andere overheidssector, marktsector, etc.) dan wel de bestemming (andere overheidssector, wachtgeld, fpu/pensioen, marktsector, etc.)". ${ }^{3}$ Het moet daarnaast gaan om een geheel nieuw dienstverband dat minimaal zes maanden zal duren. Als iemand na een tijdelijke onderbreking van minder dan drie maanden weer in dienst treedt, wordt dit niet als instroom beschouwd.

Mensen die instromen in een baan bij de politie, gaan voor het overgrote deel aan de slag bij één van de 25 regionale korpsen. Het aandeel van de instroom dat aan de slag gaat bij het Korps Landelijke Politiediensten (KLPD) en de Politieacademie is de laatste paar jaar gestegen tot $13 \%$ voor de KLPD en $17 \%$ voor de Politieacademie in 2007. Net als in de voorgaande hoofdstukken ligt de focus in dit hoofdstuk op het politiepersoneel dat werkzaam is in een executieve functie. Het merendeel van de instroom bestaat uit mensen die gaan werken in een executieve functie (in de POMO data aangeduid met 'primair proces') al dan niet in combinatie met een opleiding aan de Politieacademie. In 2003 ging 65\% van de politie-instroom aan de slag in een executieve politiefunctie, in $200574 \%$ en in 2007 77\%. Tabel 4.2 geeft een overzicht van de instroom in alle executieve functies per functieniveau. Uit deze tabel blijkt dat ongeveer de helft van de personen die instroomden in een executieve politiefunctie deze baan combineert met een politieopleiding. Dit aandeel is tussen 2003 en 2007 overigens wel gedaald.

Tabel 4.2

Politie-instroom per executief functieniveau (\%), 2003-2007

\begin{tabular}{lccc} 
& 2003 & 2005 & 2007 \\
& $\%$ & $\%$ & $\%$ \\
\hline Leidinggevend primair proces & 8 & 5 & 2 \\
\hline Primair proces schaal 4-5 & 21 & 24 & 21 \\
\hline Primair proces schaal 6-8 & 14 & 25 & 25 \\
Primair proces schaal 9-11* & - & - & 7 \\
In opleiding & 58 & 46 & 100 \\
Totaal & 100 & 100 & 44 \\
* Deze antwoordoptie is niet aanwezig in de vragenlijsten van de instromers in 2003 en 2005. \\
Bron: BZK (POMO)
\end{tabular}

3. Ministerie van Binnenlandse Zaken en Koninkrijksrelaties (2007), Personeels- en Mobiliteitsonderzoek Overheidspersoneel 2006, Den Haag. 


\section{Kenmerken van de instroom in een executieve politiefunctie}

Welke kenmerken hebben de instromers in een executieve politiefunctie en wijken deze af van de kenmerken van het totale aantal politiemensen werkzaam in het primaire proces? Door instroomgegevens uit POMO te vergelijken met gegevens afkomstig uit de Kerngegevens Overheidspersoneel en de KOSMOS Kennisbank is het mogelijk om de instromers te vergelijken met het totale personeelsbestand werkend in een executieve functie op de kenmerken geslacht en leeftijd (zie tabel 4.3). De instromers in de jaren 2003, 2005 en 2007 blijken veel vaker van het vrouwelijk geslacht te zijn dan het totale personeel en ook zijn de instromers jonger in vergelijking tot het totale personeelsbestand werkzaan in het primaire proces. In het vervolg van deze subparagraaf komen de volgende kenmerken van de instromers nog aan bod: herkomst, hoogst voltooide opleiding naar richting en naar niveau en arbeidsmarktpositie.

\section{Tabel 4.3}

Instroom van executief politiepersoneel en het politiepersoneel executief totaal naar geslacht en leeftijd (\%), 2003-2007

\begin{tabular}{lcccccc} 
& \multicolumn{3}{c}{$\begin{array}{c}\text { Instroom politiepersoneel } \\
\text { executief }\end{array}$} & & \multicolumn{3}{c}{$\begin{array}{c}\text { Politiepersoneel } \\
\text { executief* }\end{array}$} \\
& 2003 & 2005 & 2007 & 2003 & 2005 & 2007 \\
Geslacht & $\%$ & $\%$ & $\%$ & $\%$ & $\%$ & $\%$ \\
Man & 62 & 66 & 63 & 80 & 78 & 77 \\
Vrouw & 38 & 34 & 37 & 20 & 22 & 23
\end{tabular}

\begin{tabular}{|c|c|c|c|c|c|c|}
\hline \\
\hline 15-24 jaar & 48 & 35 & 38 & 10 & 10 & 11 \\
\hline 25-34 jaar & 27 & 31 & 32 & 23 & 23 & 24 \\
\hline 35-44 jaar & 18 & 22 & 19 & 30 & 28 & 25 \\
\hline 45-54 jaar & 7 & 11 & 9 & 30 & 32 & 32 \\
\hline 55 jaar en ouder & 0 & 1 & 2 & 7 & 8 & 9 \\
\hline
\end{tabular}

Bron: BZK (POMO) / BZK (Kerngegevens overheidspersoneel, KOSMOS Kennisbank)

Een steeds groter deel van de Nederlandse bevolking bestaat uit personen van nietwesterse allochtone afkomst (volgens de wet SAMEN) ${ }^{4}$ en dit aandeel zal in de

4. Volgens de Wet SAMEN behoort iemand "tot een etnische minderheid indien hij/zij zelf, zijn/ haar vader of zijn/haar moeder is geboren in één van de volgende landen of werelddelen: voormalig Joegoslavië, Turkije, Afrika, Zuid- en Midden-Amerika of Azië (exclusief voormalig Nederlands-Indië (geboren voor 1949) en Japan)". Citaat uit Ministerie van Binnenlandse Zaken en Koninkrijksrelaties (2007), Personeels- en Mobiliteitsonderzoek Overheidspersoneel 2006, Den Haag, pagina 28. De definitie van etnische minderheid komt overeen met die van een niet-westerse allochtoon zoals deze door het CBS wordt gedefinieerd (uitgezonderd voormalig Joegoslavië) welke in de voorgaande hoofdstukken is gebruikt. In de rest van dit hoofdstuk wordt daarom ook de voorkeur gegeven aan de term nietwesterse allochtoon. 
toekomst nog verder groeien (zie hoofdstuk 3). De politie wil een afspiegeling van de Nederlandse bevolking zijn en daarom is het wenselijk dat een evenredig deel van de instroom in een executieve politiefunctie van niet-westerse allochtone afkomst is. In de afgelopen jaren bleek dit aandeel echter achter te blijven bij de landelijke trend: zo was in $20036 \%$ van de instromers van niet-westerse afkomst, in $20059 \%$ en in 2007 $5 \%$.

Voor de meeste politiefuncties is een vooropleiding op minimaal middelbaar niveau (MBO of HAVO/VWO) nodig. Dit is ook terug te zien in tabel 4.4 die laat zien wat de hoogst voltooide opleiding is van de politieinstromers: meer dan de helft heeft een $\mathrm{HAVO} / \mathrm{VWO}$ - of een MBO-opleiding voltooid. In de afgelopen jaren is het aandeel personen met een afgeronde opleiding op lager niveau enigszins gedaald en dat van personen met een $\mathrm{HBO}$ - of WO-diploma gestegen.

Tabel 4.4

Politie-instroom executief naar niveau van hoogst voltooide opleiding (\%), 2003-2007

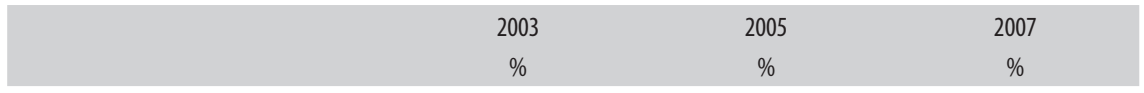

\begin{tabular}{|c|c|c|c|c|c|c|}
\hline Lager onderwijs* & 29 & & 26 & & 24 & \\
\hline Middelbaar onderwijs & 57 & & 65 & & 55 & \\
\hline - HAVO, VWO & & 19 & & 17 & & 16 \\
\hline$-\mathrm{MBO}$ & & 38 & & 47 & & 39 \\
\hline Hoger beroepsonderwijs & 11 & & 8 & & 12 & \\
\hline Wetenschappelijk onderwijs & 3 & & 2 & & 9 & \\
\hline $\begin{array}{l}\text { Totaal } \\
{ }^{*} \text { Hieronder vallen MAV } \\
\text { of alleen Basisonderwi } \\
\text { Bron: BZK (POMO) }\end{array}$ & $\begin{array}{c}100 \\
\text { eorie }\end{array}$ & MULC & $\begin{array}{l}100 \\
\text { en ho }\end{array}$ & . & $\begin{array}{r}100 \\
\text { VO, } \mathrm{HE}\end{array}$ & , VHMO \\
\hline
\end{tabular}

Van de politieinstromers met een MBO-, HBO- of WO-diploma is gevraagd welke opleidingsrichting zij hebben gevolgd (zie tabel 4.5). Uit deze tabel blijkt dat één van de vijf à zes instromers een diploma uit de 'veiligheids' richting heeft (openbare orde en veiligheid of beveiliging). Daarnaast komt echter een bont gekleurd palet aan opleidingen voor, waarin de economische, administratieve en commerciële opleidingen en de opleidingen in de sociale richtingen, maatschappelijk werk en welzijn nog het vaakst vertegenwoordig zijn. 
Tabel 4.5

Politie-instroom executief naar richting van hoogst voltooide opleiding (\%), 2003 en $2007^{*}$

\begin{tabular}{lcc} 
& 2003 & 2007 \\
& $\%$ & $\%$ \\
\hline Economisch, administratief, commercieel & & 22 \\
\hline Openbare orde en veiligheid, beveiliging & 32 & 21 \\
\hline Sociale richtingen, maatschappelijk werk, welzijn & 14 & 9 \\
\hline Techniek, wis- en natuurwetenschappen** & 19 & 6 \\
\hline Rechten, bestuurskunde & 11 & 6 \\
\hline Lerarenopleiding, onderwijskunde & 6 & 5 \\
\hline Persoonlijke verzorging, voeding, horeca*** & 4 & 4 \\
\hline Medisch, paramedisch, gezondheidszorg & 4 & 3 \\
\hline Agrarisch, natuur en milieu & - & 3 \\
\hline Letteren, kunst en cultuur & 3 & 2 \\
\hline Transport, vervoer en logistiek & 2 & 2 \\
\hline Informatica, ICT, automatisering & 2 & 2 \\
\hline Bouwkunde, weg- en waterbouw & 1 & 1 \\
\hline Anders*** & 1 & 13 \\
\hline Totaal & 4 & 100 \\
\hline
\end{tabular}

* Voor de instromers van 2005 is informatie over de opleidingsrichting niet beschikbaar.

* Deze antwoordcategorie droeg in 2003 de naam "Overige techniek".

** Deze antwoordcategorieën ontbraken in de vragenlijst voor de instromers van 2003.

Bron: BZK (POMO)

Tabel 4.6

Politie-instroom executief naar arbeidsmarktpositie (\%), 2003-2007

$\begin{array}{cccc}2003 & 2005 & 2007 \\ & \% & \% & \%\end{array}$

\begin{tabular}{lccc} 
Werkend in loondienst (niet via uitzend- of detacheringbureau of WiW-instelling) & 63 & 67 & 63 \\
\hline Schoolverlater & 14 & 11 & 13 \\
\hline Werkend via uitzendbureau of detacheringbureau & 7 & 7 & 8 \\
\hline Werkend als zelfstandige, freelancer of meewerkend gezinslid & 5 & 2 & 2 \\
Werkloos met uitkering & 3 & 4 & 2 \\
\hline Zonder werk en zonder uitkering & 1 & 2 & 1 \\
\hline Herintreder* & - & - & 1 \\
\hline Arbeidsongeschikt (volledig of gedeeltelijk) & 0 & 0 & 0 \\
Werkend in kader van de WiW & 0 & 0 & 0 \\
\hline Overig & 7 & 7 & 9 \\
Totaal & *Deze antwoordcategorie was niet aanwezig in de vragenlijsten voor de instromers in 2003 en 2005. \\
Bron: BZK (POMO) & 100 & 100
\end{tabular}

Wat 'deden' de instromers voordat ze in een executieve functie bij de politie begonnen? In tabel 4.6 is te zien dat ongeveer driekwart van de instromers al werkte voordat ze bij de politie aan de slag gingen. De meesten hadden voorheen een baan in loondienst 
(twee derde van alle instromers), daarnaast werkte $7 \%$ tot $8 \%$ op uitzend- of detacheringsbasis en een enkeling werkte voor zichzelf of voor een gezinslid. Een andere groep van substantiële omvang wordt gevormd door de schoolverlaters. In de periode 2003$2007 \mathrm{kwam}$ II\% tot I4\% van de instromers vrijwel rechtstreeks uit de schoolbanken.

Degenen die bij de politie gaan werken en daarvoor al werkzaam waren, deden dit vaak in een dienstverlenend beroep buiten de overheid, zoals de zakelijke of commerciële dienstverlening of in de handel of de horeca (zie tabel 4.7). Ook bestaat een deel van de instroom uit 'doorstromende' politiemensen. Daarnaast was een klein deel al bij de overheid werkzaam, bijvoorbeeld bij Defensie, in de Zorg of bij het Rijk, etc.

\section{Tabel 4.7}

Politie-instroom executief naar sector van de vorige baan (\%), 2003-2007

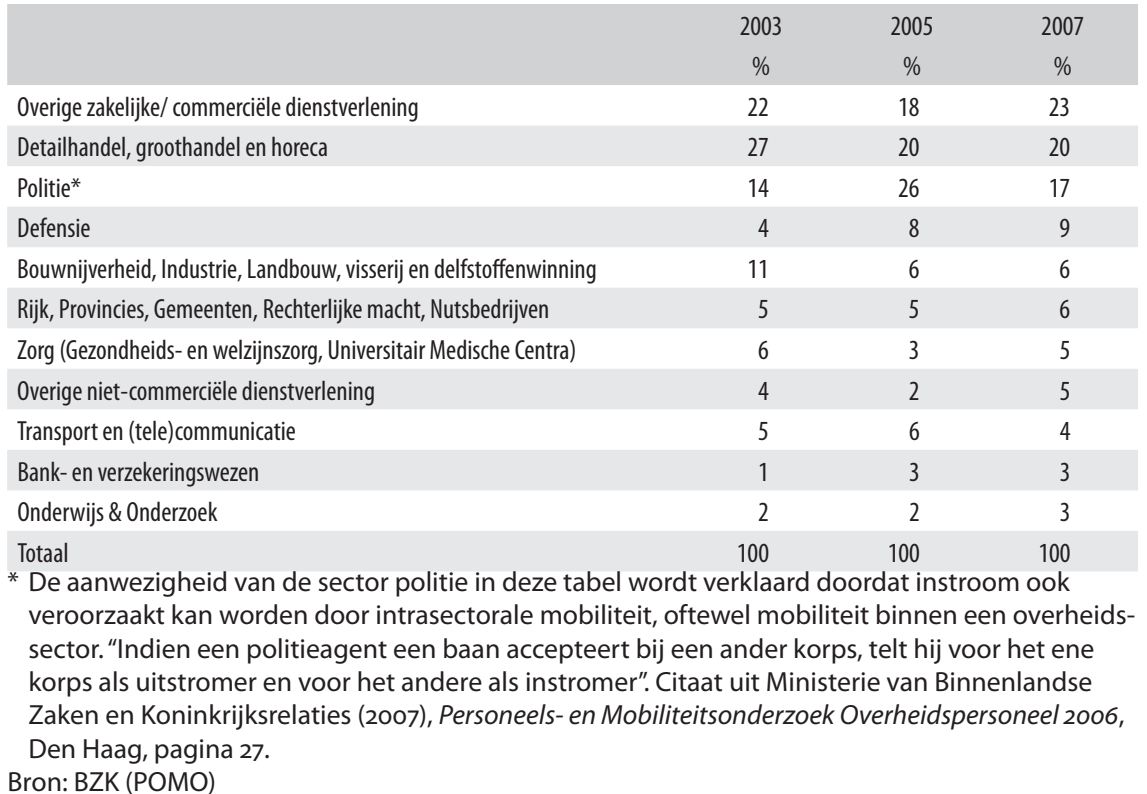

\section{Pullfactoren van een executieve politiefunctie (expliciet)}

In het Mobiliteitsonderzoek van BZK wordt rechtstreeks aan instromers gevraagd welke factoren een rol hebben gespeeld in de keuze voor de specifieke baan, in dit geval een executieve politiefunctie. Deze pullfactoren worden in dit hoofdstuk de expliciete pullfactoren genoemd en komen in deze subparagraaf aan bod. Daarnaast is uit antwoorden op andere vragen uit het Mobiliteitsonderzoek af te leiden welke andere, meer impliciete pullfactoren een rol kunnen hebben gespeeld bij de keuze voor een executieve politiefunctie. Deze zogenaamde impliciete pullfactoren worden in de volgende subparagraaf besproken. 
In tabel 4.8 wordt een overzicht gegeven van zeventien mogelijke pullfactoren. Bij elke factor is aan de instromers gevraagd naar het belang van deze factor in de keuze voor de specifieke baan. Ze konden kiezen uit de antwoordopties: "helemaal niet belangrijk", "niet zo belangrijk", "neutraal", "redelijk belangrijk" of "heel belangrijk". De percentages in tabel 4.8 geven per factor aan welk percentage van de instromers deze factor "redelijk belangrijk" of "heel belangrijk" vond in de keuze voor de specifieke baan.

Meteen valt op dat de vier belangrijkste pullfactoren in elk van de drie geanalyseerde jaren hetzelfde zijn. Veruit de belangrijkste reden is de inhoud van het werk, gevolgd door de loopbaanontwikkelingsmogelijkheden, zelfstandigheid \& verantwoordelijkheid en de relatie met collega's. In 2003 en 2005 werd de top 5 gecompleteerd door de factor resultaatgerichtheid van de organisatie, maar deze factor is in 2007 verdrongen van die $5^{\mathrm{e}}$ plaats door de factor werkplek/fysieke omstandigheden. Pas daarna worden de secundaire en primaire arbeidsvoorwaarden als pullfactor van belang genoemd.

\section{Tabel 4.8}

Politie-instroom executief \% dat pullfactor redelijk of heel belangrijk vond in keuze voor nieuwe $\operatorname{baan}^{5}(\%), 2003-2007$

$\begin{array}{cccc}2003 & 2005 & 2007 \\ & \% & \% & \%\end{array}$

\begin{tabular}{llll}
\hline Inhoud van het werk & 95 & 93 & 94 \\
\hline Loopbaanontwikkelingsmogelijkheden & 88 & 86 & 81 \\
\hline Mate van zelfstandigheid en/of verantwoordelijkheden & 91 & 89 & 81 \\
\hline Relatie met collega's & 77 & 76 & 73 \\
\hline Werkplek/fysieke omstandigheden & 58 & 54 & 61 \\
\hline Secundaire arbeidsvoorwaarden & 64 & 60 & 58 \\
\hline Primaire arbeidsvoorwaarden & 59 & 57 & 57 \\
\hline Baan kan worden gecombineerd met de thuissituatie & 54 & 55 & 54 \\
\hline Flexibiliteit in de arbeidsvoorwarden & 57 & 52 & 54 \\
\hline Resultaatgerichtheid van de organisatie & 65 & 61 & 52 \\
\hline Hoeveelheid werk* & - & 54 & 48 \\
\hline Wijze waarop direct leidinggevende leiding geeft & 55 & 53 & 48 \\
\hline Informatievoorziening en communicatie binnen de organisatie & 51 & 54 & 45 \\
\hline Wijze waarop de organisatie wordt bestuurd & 57 & 51 & 43 \\
\hline Werkdruk & 37 & 34 & 40 \\
\hline Functie betekent een promotie & 45 & 41 & 39 \\
\hline Kosten van het levensonderhoud in de standplaats/regio \\
* Deze antwoordcategorie ontbrak in de vragenlijst voor de instromers van 2003.
\end{tabular}

5. De omschrijving van sommige pullfactoren in de vragenlijst voor de instromers van 2003 wijkt af van de omschrijving in de vragenlijsten voor de instromers van 2005 en 2007 . In tabel 4.8 staan de omschrijvingen zoals gebruikt in de vragenlijsten van 2005 en 2007 vermeld. In bijlage B4.I staan ter vergelijking de omschrijvingen van de pullfactoren in alle drie de vragenlijsten vermeld. 
Het relatieve belang van een pullfactor kan variëren al naar gelang iemands geslacht, leeftijd, opleidingsniveau of herkomst. Zo is de top 3 bij zowel de mannen als de vrouwen gelijk aan dat van de totale groep. Echter, vrouwen hechten iets meer belang dan mannen aan zaken als de manier van leiding geven, de informatievoorziening/ communicatie, de werkdruk en een stukje flexibiliteit zowel in het combineren van het werk met de thuissituatie als in de arbeidsvoorwaarden.

De inhoud van het werk is voor alle leeftijdsgroepen in vrijwel alle jaren de belangrijkste ' $\mathrm{x}$-factor' van het politiewerk. Echter, de jongere instromers (I5-24 jaar) worden vaker aangetrokken door de loopbaanmogelijkheden. De aantrekkingskracht van deze factor neemt af met het klimmen der jaren. Ook de relatie met collega's is voor de jongste leeftijdsgroep vaker van belang geweest om voor een politiejob te kiezen. De groep 45-54 jaar wordt daarentegen weer net iets vaker over de streep getrokken door de mate van zelfstandigheid en verantwoordelijkheden van een baan bij de politie. Dit is overigens ook belangrijk voor de $15-24$-jarige instromers en minder belangrijk voor de middengroepen van 25-34 en 35-44 jaar.

De inhoud van het werk staat ook bij alle opleidingsniveaus bovenaan de lijst van pullfactoren. Daarachter ontstaan echter enkele markante verschillen. Zo blijkt dat de relatie met collega's en de primaire en secundaire arbeidsvoorwaarden belangrijkere pullfactoren zijn naarmate instromers lager zijn opgeleid. Ook bij de manier waarop de organisatie bestuurd wordt en de manier waarop de direct leidinggevende leiding geeft, zien we hetzelfde patroon: een baan bij de politie wordt aantrekkelijker door deze aspecten naarmate men lager is opgeleid. Instromers met een HBO- of WOdiploma daarentegen vinden de eerder genoemde top 3 (werkinhoud, zelfstandigheid/ verantwoordelijkheid en loopbaanontwikkelingsmogelijkheden) heel belangrijke redenen om voor een baan bij de politie te kiezen, en pas daarna de relatie met collega's. De rest van de pullfactoren heeft in het keuzeproces van deze hoger opgeleide instromers nauwelijks een rol gespeeld.

Bij de analyse van de pullfactoren naar herkomst (autochtoon versus niet-westerse allochtoon) vallen twee aspecten op. Ten eerste schrijven instromers van niet-westerse allochtone afkomst in de jaren 2003 en 2007 een veel grotere aantrekkingskracht toe aan de loopbaanontwikkelingsmogelijkheden van een baan bij de politie dan de autochtone instromers in die jaren. Verder springen er bij de autochtone instromers steeds vijf pullfactoren duidelijk boven de rest uit, terwijl de niet-westerse allochtone instromers een veel breder spectrum van pullfactoren een rol laten spelen in de keuze om bij de politie te gaan werken. Naast de eerder genoemde top 5 van pullfactoren spelen de primaire en secundaire arbeidsvoorwaarden, de mogelijkheden om de baan te combineren met de thuissituatie en flexibele arbeidsvoorwaarden voor instromers van niet-westerse afkomst ook een belangrijke rol in de keuze voor een baan bij de politie. ${ }^{6}$

6. Deze pullfactoren komen sterk overeen met de pullfactoren die vaker door vrouwen worden genoemd. Indien de niet-westerse allochtone instromers voornamelijk van het vrouwelijk geslacht zijn in de bestudeerde jaren, zou dit de overeenkomst tussen de pullfactoren kunnen verklaren. Wegens de korte doorlooptijd van dit onderzoek is deze mogelijke verklaring niet getoetst met behulp van de data. 


\section{Pullfactoren van een executieve politiefunctie (impliciet)}

Naast de hiervoor besproken expliciete pullfactoren (zo genoemd omdat ze expliciet als zodanig zijn voorgelegd aan de instromers) kunnen ook andere, meer impliciete, pullfactoren een rol hebben gespeeld bij het kiezen voor een specifieke executieve politiefunctie. Dit geldt voornamelijk voor de 'baan-switchers' oftewel degenen die voor zij aan hun baan bij de politie begonnen een andere baan hadden. De volgende impliciete pullfactoren komen in deze subparagraaf aan bod: verandering in baanomvang, soort dienstverband, salaris en functieniveau. Er wordt gekeken in hoeverre instromers er door hun nieuwe functie bij de politie op vooruitgegaan zijn wat deze aspecten betreft. Daarnaast kan het werken bij de politie als zodanig of het werken bij de overheid een rol van betekenis hebben gespeeld bij de keuze voor een baan bij de politie. Ook deze factor komt in de subparagraaf aan bod.

\section{Baanomvang}

Het aandeel instromers dat fulltime (d.w.z. 33 uur per week of meer) werkt in de nieuwe functie is aanmerkelijk hoger dan het aandeel fulltime werkende instromers in de vorige baan (zie tabel 4.9). Het lijkt er dus op dat een deel van de instromers hun baan in omvang heeft zien toenemen door de overstap naar de politie. Wel is er sprake van een lichte daling in het aandeel instromers dat fulltime bij de politie aan de slag is gegaan in de periode 2003-2007.

Tabel 4.9

Politie-instroom executief naar omvang van de nieuwe en de vorige baan (\%), 2003-2007

\begin{tabular}{lccc} 
& 2003 & 2005 & 2007 \\
& $\%$ & $\%$ & $\%$ \\
\hline Fulltime werkend in nieuwe baan & 94 & 92 & 88 \\
Fulltime werkend in vorige baan & 78 & 82 & 72
\end{tabular}

Bron: BZK (POMO)

\section{Soort dienstverband}

De meerderheid van de nieuwkomers bij de politie start met een tijdelijk contract, maar wel met uitzicht op een vast dienstverband (zie linkerhelft van tabel 4.IO). Dit aandeel is overigens wel enigszins afgenomen in de jaren 2003-2007 ten gunste van het aandeel vaste banen. Andere soorten dienstverbanden komen in deze periode nauwelijks voor. Wanneer we naar de rechterhelft van tabel 4.Io kijken, lijkt het er op dat een deel van de al werkende instromers een lagere werkzekerheid overheeft voor een baan bij de politie. Immers, het aandeel vaste dienstverbanden is in de oude functie beduidend hoger dan in de nieuwe functie. 
Tabel 4.10

Politie-instroom executief naar soort dienstverband van de nieuwe en de vorige baan (\%), 20032007

\begin{tabular}{lrrrrrrr} 
& \multicolumn{3}{c}{ Nieuwe baan } & \multicolumn{3}{c}{ Vorige baan } \\
& 2003 & 2005 & 2007 & 2003 & 2005 & 2007 \\
& $\%$ & $\%$ & $\%$ & $\%$ & $\%$ & $\%$ \\
\hline Vast dienstverband & 31 & 36 & 41 & 61 & 68 & 62 \\
\hline Tijdelijk contract met uitzicht op een vast dienstverband & 64 & 59 & 54 & 17 & 15 & 17 \\
\hline Tijdelijk contract zonder uitzicht op een vast dienstverband & 1 & 2 & 2 & 15 & 11 & 14 \\
\hline Dienstverband vanwege een bijzondere regeling & 2 & 0 & 1 & 0 & 0 & 1 \\
\hline Overig & 2 & 2 & 3 & 8 & 6 & 6 \\
\hline Totaal & 100 & 100 & 100 & 100 & 100 & 100
\end{tabular}

Bron: BZK (POMO)

\section{Salaris}

Aan de instromers die al een betaalde baan hadden, is gevraagd in welke mate hun salaris is veranderd door hun nieuwe baan bij de politie (zie tabel $4 . \mathrm{II}$ ). $43 \%$ tot $32 \%$ van de instromers in de jaren 2003-2007 is er in salaris op vooruit gegaan, terwijl ruim een derde van de instromers er in salaris op achteruit is gegaan. Het lijkt er overigens op dat de oude en nieuwe salarissen enigszins convergeren door de jaren heen: steeds vaker geven instromers aan dat hun salaris (vrijwel) gelijk is gebleven na hun overstap naar de politie. Een hoger bruto maandsalaris kan zowel door een hoger bruto uurloon als door een grotere baanomvang worden veroorzaakt. Aangezien het percentage fulltime werkenden in de nieuwe baan hoger is dan in de oude baan (zie tabel 4.9), spelen in tabel 4.II zeer waarschijnlijk beide effecten een rol.

\section{Tabel 4.11}

Politie-instroom executief naar verandering in salaris tussen de nieuwe en de vorige baan (\%)*, 2003-2007

\begin{tabular}{lccc} 
& 2003 & 2005 & 2007 \\
& $\%$ & $\%$ & $\%$ \\
\hline Meer gaan verdienen & 43 & 36 & 32 \\
(Vrijwel) gelijk & 20 & 27 & 33 \\
Minder gaan verdienen & 37 & 37 & 35 \\
Totaal & 100 & 100 & 100
\end{tabular}

* De verandering in salaris betreft een structurele verandering in het bruto maandsalaris. Het overgrote deel van de jaarlijkse instroom bij de politie had daarvoor een betaalde baan. Slechts 5\% (2003), 7\% (2005 en 2007) had geen betaalde baan voor men aan deze politiefunctie begon. De percentages in de tabel zijn daarom alleen gebaseerd op degenen die al een betaalde baan hadden.

Bron: BZK (POMO)

Wanneer we de inkomensverandering van de baanswitchers nader bekijken naar geslacht, herkomst, opleidingsniveau en leeftijd, vallen een aantal zaken op. Ten eerste blijken vrouwen in alle drie de geanalyseerde jaren vaker dan mannen aan te geven evenveel of meer te verdienen door hun nieuwe politiefunctie. In 2007 verdiende bijvoorbeeld $69 \%$ van de vrouwelijke instromers evenveel of meer dan in de vorige 
baan ten opzichte van $62 \%$ van de mannelijke instromers. Verder blijkt dat de instromers van autochtone afkomst hun salaris vaker handhaven of verbeteren dan de instromers van niet-westerse allochtone afkomst.

Wanneer we kijken naar leeftijd en naar hoogst voltooide opleiding wordt het beeld iets diffuser en varieert het tussen de jaren. Wat betreft leeftijd zijn het in 2003 en 2005 vooral de jongeren ( $15-24$ jaar) die het vaakst aangeven hetzelfde of meer te verdienen, maar in 2007 geeft juist de groep 45-54 jarigen steeds vaker aan hetzelfde of meer salaris te verdienen dan in de vorige baan. Wat betreft opleidingsniveau zijn het in 2003 en 2005 aanvankelijk de lager en middelbaar opgeleiden die het vaakst aangeven hun salaris te handhaven of te verhogen. In 2007 echter, zijn het vooral de instromers met een HBO-opleiding die aangeven hetzelfde of meer te verdienen in hun nieuwe politiefunctie.

\section{Functieniveau}

Kunnen werken op een hoger functieniveau kan een belangrijke drijfveer zijn om over te stappen naar een andere baan. Instromers is gevraagd hoe het niveau van hun nieuwe functie bij de politie zich verhoudt tot het niveau van hun vorige baan (zie tabel 4.I2). Iets meer dan de helft van de instromers is er in de periode 2003-2007 qua functieniveau op vooruitgegaan. Daarnaast handhaaft gemiddeld ongeveer een kwart de status quo. Slechts $16 \%$ tot $20 \%$ werkt op een lager functieniveau dan eerst.

\section{Tabel 4.12}

Politie-instroom executief naar aansluiting functieniveau tussen nieuwe en vorige baan (\%), 20032007

\begin{tabular}{lcccc} 
& 2003 & 2005 & 2007 \\
& $\%$ & $\%$ & $\%$ \\
\hline Het niveau van mijn nieuwe functie is beduidend lager dan dat van mijn vorige functie & 6 & 6 & 8 \\
\hline Het niveau van mijn nieuwe functie is enigszins lager dan dat van mijn vorige functie & 10 & 12 & 12 \\
\hline Het niveau van mijn nieuwe functie is vergelijkbaar met mijn vorige functie & 27 & 27 & 22 \\
\hline Het niveau van mijn nieuwe functie is enigszins hoger dan dat van mijn vorige functie & 34 & 36 & 29 \\
\hline Het niveau van mijn nieuwe functie is beduidend hoger dan dat van mijn vorige functie & 24 & 18 & 29 \\
\hline Totaal & 100 & 100 & 100
\end{tabular}

Bron: BZK (POMO)

De aansluiting van het functieniveau tussen de nieuwe en de vorige baan blijkt te verschillen naar herkomst, leeftijd en opleidingsniveau. ${ }^{7}$ Instromers van autochtone afkomst blijken structureel vaker in te stromen in een politiebaan met een vergelijkbaar of hoger functieniveau dan hun vorige baan dan niet-westerse allochtone instromers. De jongere instromers ( $15-24$ jaar) geven het vaakst aan nu een hoger functieniveau te hebben dan in hun vorige baan al is dit percentage licht gedaald in de periode 2003-2007 (91\% naar 86\%). Daarentegen werken instromers van 45-54 jaar

7. Voor een vergelijking tussen de subgroepen geslacht, etniciteit, opleidingsniveau en leeftijd is berekend hoeveel procent van elke groep heeft aangegeven nu een functie met een vergelijkbaar of een hoger functieniveau te hebben. Hiervoor zijn de antwoordcategorieën $3 \mathrm{t} / \mathrm{m} 5$ bij elkaar genomen. 
over de jaren heen juist steeds vaker op een hoger functieniveau $(75 \%$ in 2003 naar $84 \%$ in 2007).

Over het algemeen stappen instromers met een opleiding op lager of middelbaar niveau iets vaker in een politiefunctie die van een hoger niveau is dan de vorige functie dan instromers met een HBO- of WO-diploma op zak. Dit is overigens logisch: jongere instromers hebben minder tijd gehad om opleidingen te volgen en te groeien in functies naar een hoger niveau, dus hun 'groeiruimte' qua functieniveau is groter dan die van oudere instromers. Hetzelfde geldt voor mensen die een lagere of middelbare opleiding hebben genoten. Hun eerste functie(s) zal/zullen ook van dat niveau zijn wat ook hen meer groeiruimte laat dan mensen die door hun hogere opleidingsniveau (HBO/WO) al in hun eerste baan op een hoger functieniveau kunnen instappen. Van de mensen met een HBO/WO-diploma op zak geeft overigens nog ongeveer driekwart aan dat ze nu een functie hebben op minimaal een vergelijkbaar niveau als in hun vorige functie.

\section{Voorkeur overheidssector en politiesector}

Naast de pullfactoren die direct met de baan als zodanig te maken hebben, kan ook het werken bij een bepaalde organisatie zoals "de overheid" of "de politie" een rol hebben gespeeld in de keuze voor een baan bij de politie. In het Mobiliteitsonderzoek zijn de stellingen "Ik heb een sterke voorkeur om bij de overheid te werken en niet in de markt of de zorgsector" en "Ik heb een sterke voorkeur om te werken bij de sector Politie en niet in een andere overheidssector" aan de instromers voorgelegd met daarbij de vraag of dit een rol heeft gespeeld in de keuze voor de nieuwe baan. De bijbehorende antwoordopties waren "helemaal geen rol", "beperkte rol", "grote rol" en "uitermate grote rol". Vervolgens zijn de antwoorden "grote rol" en "uitermate grote rol" samengevoegd. In tabel 4.13 is te zien dat iets meer dan de helft van de instromers duidelijk een sterke voorkeur heeft voor de politiesector boven één van de andere overheidssectoren. Daarnaast blijkt het feit dat een baan bij de politie betekent dat men in overheidsdienst komt, recentelijk steeds meer gewicht in de schaal legt: in 2003 speelde de voorkeur voor een baan bij de overheid i.p.v. in de markt of zorgsector bij $44 \%$ van de instromers een grote of een uitermate grote rol. Vier jaar later is dit percentage gestegen naar $73 \%$ van de instromers.

\section{Tabel 4.13}

Politie-instroom executief \% waarbij voorkeur voor overheidssector en politiesector een grote of uitermate grote rol heeft gespeeld bij keuze voor nieuwe baan, 2003-2007

\begin{tabular}{lccc} 
& 2003 & 2005 & 2007 \\
\hline Sterke voorkeur voor overheid i.p.v. markt- of zorgsector & $\%$ & $\%$ & $\%$ \\
\hline Sterke voorkeur voor politie i.p.v. een andere overheidssector & 44 & 54 & 73 \\
\hline Bron: BZK (POMO) & 54 & 51 & 61
\end{tabular}


De mannelijke instromers lijken iets meer waarde te hechten aan het werken bij de overheid dan de vrouwelijke instromers en ook de instromers in de leeftijd van I5-24 jaar vinden dit een belangrijk punt. Dit is overigens een tamelijk recent verschijnsel. $\mathrm{Al}$ met al lijkt de specifieke baan een belangrijkere pullfactor voor het werken bij de politie dan de overheidssector of de politiesector op zichzelf.

\subsection{Pushfactoren van een executieve politiefunctie}

De uitstroom van politiepersoneel (executief en ondersteunend tezamen) is relatief laag in vergelijking tot de overheidssector als geheel. De uitstroom bij de politie bedroeg namelijk $5 \%$ à $6 \%$ in de jaren 2003,2005 en 2007 , terwijl de uitstroom in de gehele overheidssector in die jaren tussen de $9 \%$ en I $2 \%$ lag. Ondanks dit relatief lage niveau is het toch van belang deze uitstroom nader te bekijken, aangezien onnodige uitstroom een verlies kan inhouden van de gedane investeringen in het politiepersoneel.

\section{Definitie en afbakening relevante groep uitstromers}

In het Mobiliteitsonderzoek wordt iemand als een uitstromer aangeduid wanneer hij of zij "in een kalenderjaar [...] uit dienst getreden is bij een overheidswerkgever [....], ongeacht de herkomst (opleiding, wachtgeld, andere overheidssector, marktsector, etc.) dan wel de bestemming (andere overheidssector, wachtgeld, fpu/pensioen, marktsector, etc.)" ${ }^{8}$ Daarnaast moet er sprake zijn van het volledig beëindigen van het dienstverband.

Tabel 4.14

Politie-uitstroom per executief functieniveau (\%), 2003-2007

\begin{tabular}{lcccc} 
& 2003 & 2005 & 2007 \\
& $\%$ & $\%$ & $\%$ \\
\hline Leidinggevend primair proces & 24 & 16 & 8 \\
\hline Primair proces schaal 4-5 & 12 & 14 & 12 \\
\hline Primair proces schaal 6-8 & 50 & 65 & 54 \\
\hline Primair proces schaal 9-11 & $*$ & $*$ & 16 \\
\hline In opleiding & 14 & 6 & 9 \\
Totaal & 100 & 100 & 100
\end{tabular}

* Categorie niet als antwoordoptie aanwezig in deze metingen.

Bron: BZK (POMO)

In de periode 2003-2007 waren vier van de vijf uitstromers uit een baan bij de politie werkzaam bij één van de 25 regiokorpsen. Ongeveer twee derde $(2003,2005)$ tot driekwart (2007) van de uitstromers was werkzaam in een executieve politiefunctie oftewel in het 'primaire proces'. Net als bij de instromers zal ook in deze paragraaf over

8. Ministerie van Binnenlandse Zaken en Koninkrijksrelaties (2007), Personeels- en Mobiliteitsonderzoek Overheidspersoneel 2006, Den Haag. 
de uitstroom uitsluitend naar mensen gekeken worden die voor het beëindigen van hun baan werkzaam waren in een executieve politiefunctie. De helft tot twee derde van de uitstromers werkzaam in een executieve politiefunctie werkte in een schaal 6-8 functie (zie tabel 4.I4). Ook vertrokken een aantal instromers (6\% in 2005 tot $14 \%$ in 2003) terwijl ze nog in opleiding waren.

De focus in deze paragraaf ligt op het detecteren van redenen waarom mensen met een executieve politiefunctie met deze functie stoppen met als doel onnodige uitstroom voorkomen. In tabel 4.I5 wordt een overzicht gegeven van de hoofdredenen die uitstromers gaven voor de beëindiging van hun baan. Een kwart tot 31\% stroomde uit wegens (vervroegd) pensioen en $21 \%$ (2003) of $9 \%(2005,2007)$ van de uitstromers werd ontslagen of kreeg geen nieuwe contract. Daarnaast nam $46 \%$ tot $59 \%$ van de uitstromende politiemensen op eigen initiatief ontslag. We kijken in het vervolg van deze paragraaf alleen naar de pushfactoren van de uitstromers die zelf ontslag hebben genomen omdat dit vertrek mogelijk kon worden voorkomen en dus onnodig zou kunnen zijn geweest. ${ }^{9}$

Tabel 4.15

Politie-uitstroom executief naar hoofdreden van beëindiging baan (\%), 2003-2007

$\begin{array}{cccc}2003 & 2005 & 2007 \\ & \% & \% & \%\end{array}$

\begin{tabular}{|c|c|c|c|}
\hline Vervroegd uittreden & 24 & 30 & 28 \\
\hline Ik ging met pensioen & 1 & 1 & 3 \\
\hline Ik werd volledig arbeidsongeschikt* & & 2 & 1 \\
\hline Ik werd gedeeltelijk arbeidsongeschikt en heb mijn baan niet behouden* & 7 & 0 & 1 \\
\hline Ik werd ontslagen door werkgever & 15 & 7 & 6 \\
\hline Mijn tijdelijk contract liep af & 6 & 2 & 3 \\
\hline Ik nam zelf ontslag & 46 & 58 & 59 \\
\hline $\begin{array}{l}\text { Totaal } \\
\text { * In de vragenlijst voor uitstromers in } 2003 \text { was er slech } \\
\text { geschiktheid in de vragenlijst opgenomen, namelijk" } \\
\text { Bron: BZK (POMO) }\end{array}$ & $\begin{array}{l}100 \\
\text { optie } \\
\text { d/ ar }\end{array}$ & $\begin{array}{l}100 \\
\text { son } \\
\text { sol }\end{array}$ & $\begin{array}{l}100 \\
\text { dson- } \\
\text { hikt". }\end{array}$ \\
\hline
\end{tabular}

\section{Kenmerken van de uitstroom vanuit een executieve politiefunctie}

In hoeverre wijken de kenmerken van de uitstromers die zelf hun baan hebben opgezegd af van het politiebestand werkzaam in een executieve functie? Volgens tabel 4.I6 blijken relatief meer mannen dan vrouwen op eigen initiatief te vertrekken, echter gezien de samenstelling van het totale executieve personeelsbestand zijn het juist de

9. Bij ontslag en arbeidsongeschiktheid is het mogelijk dat een deel hiervan te voorkomen was geweest. Dit is echter lastig te beoordelen, vandaar dat deze groepen in zijn geheel buiten beschouwing worden gelaten in het vervolg van deze paragraaf. 
vrouwen die oververtegenwoordigd zijn in de uitstroom. Hun aandeel is overigens wel afgenomen van $4 \mathrm{I} \%$ naar $32 \%$ in de periode $2003-2007$.

\section{Tabel 4.16}

Uitstroom van executief politiepersoneel dat zelf ontslag heeft genomen en het politiepersoneel executief totaal naar geslacht en leeftijd (\%), 2003-2007

\begin{tabular}{ccccccc} 
& Uitstroom politiepersoneel & \multicolumn{3}{c}{ Politiepersoneel executief* } \\
executief & & & & 2007 \\
2003 & 2005 & 2007 & 2003 & 2005 & $\%$
\end{tabular}

$\begin{array}{lllllll}\text { Geslacht } & 59 & 63 & 68 & 80 & 78 & 77 \\ \text { Man } & 51 & 37 & 32 & 20 & 22 & 23 \\ \text { Vrouw } & 41 & \end{array}$

\section{Leeftijd}

$\begin{array}{lrrrrrr}\text { 15-24 jaar } & 9 & 6 & 14 & 10 & 10 & 11 \\ 25-34 \text { jaar } & 34 & 34 & 36 & 23 & 23 & 24 \\ 35-44 \text { jaar } & 38 & 38 & 31 & 30 & 28 & 25 \\ 45-54 \text { jaar } & 19 & 21 & 19 & 30 & 32 & 32 \\ 55 \text { jaar en ouder } & 0 & 1 & 1 & 7 & 8 & 9\end{array}$

* Dit is het gemiddelde personeelsbestand in dat jaar. Voor 2003 is bijvoorbeeld het gemiddelde berekend van het personeelsbestand ultimo 2002 en ultimo 2003, etc. Dit vanwege het feit dat uitstroom gedurende het jaar een effect kan hebben op de samenstelling van het totale executieve politiepersoneelsbestand.

Bron: BZK (POMO) / BZK (Kerngegevens overheidspersoneel, KOSMOS Kennisbank)

Ook de leeftijdsgroepen 25-34 jaar en 35-44 jaar zijn oververtegenwoordigd onder de uitstromers, hoewel het aandeel van de laatstgenoemde groep wel dalend is (zie tabel 4.I6). De twee oudste leeftijdsklassen, de 45-54 en de 55-plussers, zijn daarentegen weer ondervertegenwoordigd. Bij de 55-plussers kan dit samenhangen met het feit dat zij vaker om (vervroegd) pensioensredenen uit zullen stromen en dus niet zelf ontslag nemen. Het aandeel jongeren dat uit eigen beweging vertrok is niet zo hoog in 2003 en 2005 , maar steeg in 2007 tot $14 \%$.

Een analyse van de herkomstgegeven van de uitstromers laat zien dat zij niet bovengemiddeld van niet-westerse afkomst zijn: $4 \%(2005)$ tot $7 \%(2003,2007)$ van de uitstromers zijn niet-westerse allochtonen. Verder heeft ongeveer $60 \%$ van de uitstromers een opleiding op middelbaar niveau (meestal MBO), gevolgd door $16 \%$ tot $18 \%$ dat een $\mathrm{HBO}$-opleiding heeft (zie tabel 4.I7). Deze verdeling over de opleidingsniveaus is opvallend stabiel in de onderzochte jaren. 
Tabel 4.17

Politie-uitstroom executief naar niveau van hoogst voltooide opleiding (\%), 2003-2007

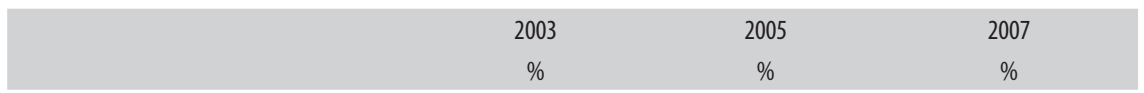

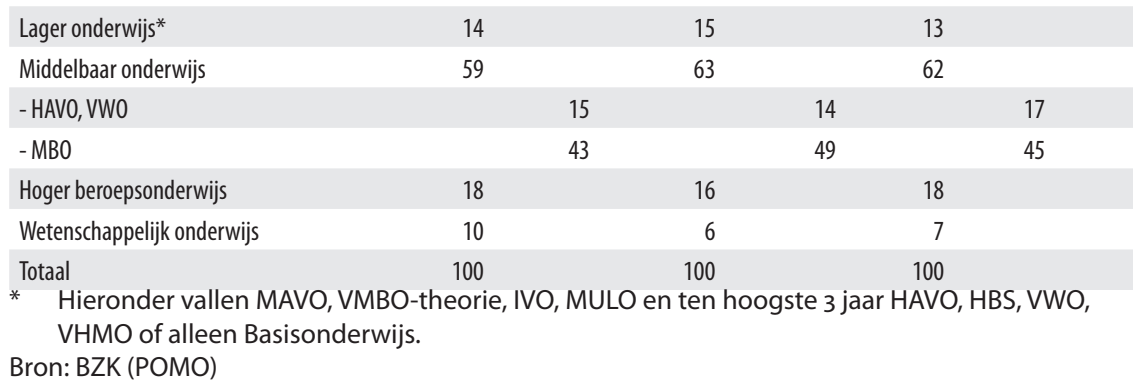

Bij de analyse van de instroom is gebleken dat intrasectorale mobiliteit een (beperkte) rol speelt bij de instroom. ${ }^{10} \mathrm{Om}$ te zien of en hoe groot de rol van intrasectorale mobiliteit is bij de uitstroom, toont tabel 4.18 wat de uitstromers zijn gaan 'doen' nadat zij hun executieve politiefunctie opzegden. Een derde (2003) tot bijna de helft (2005, 2007) van de uitstromers blijkt te vertrekken om elders bij de politie aan de slag te gaan. Dit kan in een andere functie zijn en/of in een ander korps en/of in een ander politieonderdeel. De rol van intrasectorale mobiliteit bij de uitstroom is dus aanzienlijk te noemen. Gelet op het doel van de uitstroomanalyse, zouden idealiter de respondenten die hebben aangegeven dat zij weer bij de politie aan de slag zijn gegaan, worden uitgesloten van de groep uitstromers. Echter, de aantallen uitstromers zouden hierdoor dusdanig klein worden, dat een nadere analyse onvoldoende betrouwbaar zou worden. De uitstromers die elders bij de politie aan de slag gaan, maken derhalve deel uit van de analyses in het vervolg van deze paragraaf. Verder valt in tabel 4.I8 op dat een deel van de uitstromers in een andere overheidssector aan de slag gaat. Ook besluit een aanzienlijk deel van de instromers (I2\% tot $14 \%$ ) zich niet meer aan te bieden op de arbeidsmarkt, maar te kiezen voor inactiviteit.

Io. Intrasectorale mobiliteit is mobiliteit binnen een overheidssector. "Indien een politieagent een baan accepteert bij een ander korps, telt hij voor het ene korps als uitstromer en voor het andere als instromer". Citaat uit Ministerie van Binnenlandse Zaken en Koninkrijksrelaties (2007), Personeels-en Mobiliteitsonderzoek Overheidspersoneel 2006, Den Haag, pagina 27. 
Tabel 4.18

Politie-uitstroom executief naar sector van nieuwe baan (\%), 2003-2007

\begin{tabular}{lccc|} 
& 2003 & 2005 & 2007 \\
& $\%$ & $\%$ & $\%$ \\
\hline Eigen sector & & 49 & 47 \\
\hline Rest overheid & 36 & 17 & 15 \\
\hline Marktsector & 28 & 15 & 16 \\
\hline Zorgsector & 17 & 4 & 5 \\
\hline Uitzend, detachering, WiW & 3 & 2 & 4 \\
\hline Inactiviteit & 3 & 14 & 12 \\
\hline Totaal & 13 & 100 & 100 \\
\hline Bron: BZK (POMO) & 100 & & \\
\hline
\end{tabular}

\section{Pushfactoren van een executieve politiefunctie (expliciet)}

Net als in de vorige paragraaf over de pullfactoren van een executieve politiefunctie, wordt ook in deze paragraaf over de pushfactoren een onderscheid gemaakt tussen expliciete en meer impliciete factoren. De expliciete pushfactoren zijn als zodanig aan de uitstromers voorgelegd met de vraag hoe belangrijk elke pushfactor was als reden om te stoppen met de baan en/of op zoek te gaan naar een andere baan. De antwoordopties waren: "helemaal niet belangrijk", "niet zo belangrijk", "neutraal", "redelijk belangrijk" of "heel belangrijk". In tabel 4.I9 staan de negentien mogelijke pushfactoren met daar achter de percentages die aangeven hoeveel procent van de instromers deze factor "redelijk belangrijk" of "heel belangrijk" vonden als reden om de baan bij de politie op te zeggen.

Bij de pushfactoren is er niet één factor die er duidelijk bovenuit steekt, zoals we zagen bij de pullfactoren (inhoud van het werk). Wel wordt in elk onderzocht jaar vrijwel dezelfde top 5 genoemd. Aan de pushfactor "De loopbaanmogelijkheden" (en waarschijnlijk het gebrek daaraan) wordt consequent door de meeste uitstromers het meeste belang toegekend, maar ook de inhoud van het werk en de wijze waarop de organisatie wordt bestuurd zijn belangrijke bronnen van onvrede. De top 5 wordt vervolgens gecompleteerd door de pushfactoren mate van zelfstandigheid en/of verantwoordelijkheden en de wijze waarop direct leidinggevende leiding geeft (2005, 2007). In 2003 staat de resultaatgerichtheid van de organisatie i.p.v. de wijze waarop de direct leidinggevende leiding geeft in de top 5 .

Wegens te kleine aantallen respondenten in diverse subgroepen is het alleen mogelijk om de analyse naar de expliciete pushfactoren te differentiëren naar geslacht. Mannen en vrouwen blijken echter om vergelijkbare redenen hun baan op te zeggen. In beide groepen bestaat de top 3 van belangrijkste pushfactoren uit de loopbaanmogelijkheden, de wijze waarop de organisatie wordt bestuurd en de inhoud van het werk. Pas bij de volgende plaatsen zien we in sommige jaren verschillen. Zo staat bij de mannen de pushfactor mate van zelfstandigheid en/of verantwoordelijkheden steeds 
op de vierde plaats, terwijl we daar bij de vrouwen soms de informatievoorziening en communicatie binnen de organisatie terugzien. De rol van de primaire arbeidsvoorwaarden lijkt in de loop van de drie jaren een iets belangrijkere rol te zijn gaan spelen: in 2003 vond $43 \%$ van de uitstromers dit een redelijk tot heel belangrijke reden en in 2007 vindt $59 \%$ van de uitstromers dit. Opvallend is verder dat vrouwen aanvankelijk veel vaker dan mannen aangeven dat het combineren van de baan met de thuissituatie een reden is om af te haken ( $53 \%$ tegenover $25 \%$ in 2003), maar dat dit verschil in 2007 vrijwel verdwenen is ( $49 \%$ tegenover $46 \%)$.

\section{Tabel 4.19}

Politie-uitstroom executief \% dat pushfactor redelijk of heel belangrijk vond in keuze om zelf ontslag te nemen" $(\%)$, 2003-2007

\begin{tabular}{|c|c|c|c|}
\hline & 2003 & 2005 & 2007 \\
\hline & $\%$ & $\%$ & $\%$ \\
\hline Loopbaanontwikkelingsmogelijkheden & 71 & 70 & 79 \\
\hline Inhoud van het werk & 68 & 64 & 72 \\
\hline Wijze waarop de organisatie wordt bestuurd & 72 & 59 & 72 \\
\hline Mate van zelfstandigheid en/of verantwoordelijkheden & 55 & 56 & 67 \\
\hline Wijze waarop direct leidinggevende leiding geeft & 47 & 58 & 63 \\
\hline Primaire arbeidsvoorwaarden & 43 & 51 & 59 \\
\hline Informatievoorziening en communicatie binnen de organisatie & 42 & 49 & 58 \\
\hline Resultaatgerichtheid van de organisatie & 57 & 49 & 58 \\
\hline Secundaire arbeidsvoorwaarden & 29 & 39 & 53 \\
\hline Baan kan worden gecombineerd met de thuissituatie & 36 & 42 & 47 \\
\hline Relatie met collega's & 49 & 43 & 46 \\
\hline Hoeveelheid werk* & - & 29 & 43 \\
\hline Werkplek/fysieke omstandigheden & 22 & 31 & 42 \\
\hline Flexibiliteit in de arbeidsvoorwaarden & 28 & 28 & 41 \\
\hline Kosten van het levensonderhoud in de standplaats/regio & 17 & 23 & 38 \\
\hline Werkdruk & 31 & 27 & 36 \\
\hline Onheuse bejegening door collega's & 16 & 23 & 27 \\
\hline Dreiging baan te verliezen om andere reden & 12 & 14 & 23 \\
\hline Dreiging baan te verliezen bij reorganisatie & 10 & 12 & 20 \\
\hline
\end{tabular}

* Deze antwoordcategorie ontbrak in de vragenlijst voor de uitstromers van 2003.

Bron: BZK (POMO)

II. De omschrijving van sommige pushfactoren in de vragenlijst voor de uitstromers van 2003 wijkt af van de omschrijving in de vragenlijsten voor de uitstromers van 2005 en 2007 . In tabel 4.19 staan de omschrijvingen zoals gebruikt in de vragenlijsten van 2005 en 2007 vermeld. In tabel B4.I in de bijlage staan ter vergelijking de omschrijvingen van de pullfactoren van alle drie de vragenlijsten vermeld. 


\section{Pushfactoren van een executieve politiefunctie (impliciet)}

Naast de pushfactoren die expliciet als zodanig zijn voorgelegd aan de uitstromers zijn er ook een aantal impliciete pushfactoren te onderscheiden. Dit zijn de factoren baanomvang, het soort dienstverband, het salaris en het funtieniveau. Deze aspecten zijn alleen onderzocht voor die uitstromers die uitstroomden naar een andere baan ( $86 \%$ tot $88 \%$ van de uitstromers, zie tabel 4.18$)$.

\section{Baanomvang en soort dienstverband}

Bij de politie werkte men doorgaans in een fulltime dienstverband ( 33 uur of meer): $83 \%$ tot $88 \%$ van de uitstromers had bij de politie een fulltime baan. Van de uitstromers die in een andere baan begonnen, werkt ruim $80 \%$ weer fulltime. Wat betreft het soort dienstverband blijkt dat de meeste uitstromers bij de politie een vast dienstverband hadden $(87 \%$ tot $92 \%$, zie tabel 4.20 ). Na de overstap naar een andere baan hebben uitstromers vaker een tijdelijk contract met uitzicht op een vast dienstverband in de jaren 2005 en 2007.

Tabel 4.20

Politie-uitstroom executief naar soort dienstverband van de nieuwe en de vorige baan (\%), 20032007

\begin{tabular}{lrrrrrrr} 
& \multicolumn{3}{c}{ Nieuwe baan } & \multicolumn{3}{c}{ Vorige baan } \\
& 2003 & 2005 & 2007 & 2003 & 2005 & 2007 \\
& $\%$ & $\%$ & $\%$ & $\%$ & $\%$ & $\%$ \\
\hline Vast dienstverband & 85 & 75 & 69 & 87 & 92 & 87 \\
\hline Tijdelijk contract met uitzicht op een vast dienstverband & 14 & 21 & 27 & 12 & 7 & 11 \\
\hline Tijdelijk contract zonder uitzicht op een vast dienstverband & 1 & 1 & 3 & 0 & 0 & 0 \\
\hline Dienstverband vanwege een bijzondere regeling & 0 & 3 & 1 & 0 & 0 & 0 \\
\hline Overig & 0 & 0 & 0 & 1 & 1 & 1 \\
\hline Totaal & 100 & 100 & 100 & 100 & 100 & 100 \\
Bron: BZK (POMO) & & & & & &
\end{tabular}

\section{Salaris}

In tabel 4.I9 hebben we gezien dat de primaire arbeidsvoorwaarden in de loop van de periode 2003-2007 een iets belangrijke rol zijn gaan spelen. Ook tabel 4.2I laat zien dat voor een aanzienlijk deel van de uitstromers die weer in een ander baan aan de slag gingen, hun salaris er op vooruit is gegaan door de overstap. Dit aandeel daalt overigens wel tussen 2003 en 2007 : van $53 \%$ naar $43 \%$. 
Tabel 4.21

Politie-uitstroom executief naar verandering in salaris tussen de nieuwe en de vorige baan (\%)*, 2003-2007

$\begin{array}{cccc}2003 & 2005 & 2007 \\ & \% & \% & \%\end{array}$

\begin{tabular}{|llll}
\hline Meer gaan verdienen & 53 & 50 & 43 \\
\hline (Vrijwel) gelijk & 24 & 37 & 42 \\
\hline Minder gaan verdienen & 22 & 13 & 14
\end{tabular}

* De verandering in salaris betreft een structurele verandering in het bruto maandsalaris.

Bron: BZK (POMO)

\section{Functieniveau}

Gemiddeld iets minder dan de helft van de uitstromers die daarna weer een nieuwe baan beginnen, ziet zijn of haar functieniveau toenemen (zie tabel 4.22). Daarnaast komt ongeveer een kwart terecht in een functie van hetzelfde niveau. Slechts een klein deel van de uitstromers komen terecht in een functie die van een lager niveau is dan hun oude politiefunctie. De mannelijke uitstromers blijken overigens vaker dan hun vrouwelijke tegenhangers een baan van gelijk of hoger niveau te vinden. Het verschil wordt in de loop der jaren echter kleiner.

\section{Tabel 4.22}

Politie-uitstroom executief naar aansluiting functieniveau tussen nieuwe en vorige baan (\%), 20032007

\begin{tabular}{lccc} 
& 2003 & 2005 & 2007 \\
& $\%$ & $\%$ & $\%$ \\
\hline Het niveau van mijn nieuwe functie is beduidend lager dan dat van mijn vorige functie & 7 & 4 & 7 \\
\hline Het niveau van mijn nieuwe functie is enigszins lager dan dat van mijn vorige functie & 6 & 11 & 11 \\
\hline Het niveau van mijn nieuwe functie is vergelijkbaar met mijn vorige functie & 34 & 43 & 32 \\
\hline Het niveau van mijn nieuwe functie is enigszins hoger dan dat van mijn vorige functie & 38 & 32 & 33 \\
\hline Het niveau van mijn nieuwe functie is beduidend hoger dan dat van mijn vorige functie & 14 & 10 & 16 \\
\hline Totaal & 100 & 100 & 100 \\
Bron: BZK (POMO) & & & $\%$
\end{tabular}

Van de impliciete pushfactoren lijken baanomvang en soort dienstverband geen redenen te zijn om de oude politiebaan op te zeggen. Het verdienen van een hoger salaris en het werken in een functie van een hoger niveau lijken daarentegen wel factoren die een rol hebben gespeeld bij de keuze om zelf ontslag te nemen.

\subsection{Samenvatting}

De instroom en vooral de uitstroom is, relatief gezien, bij de politie lager dan bij de overheid als geheel. De politie-instroom gaat voor twee derde tot driekwart aan de slag in een executieve functie en bevat meer vrouwen en jongeren dan het totale execu- 
tieve politiebestand. De instromers hebben meestal een $\mathrm{MBO}$ - of HAVO/VWOopleiding gehad, maar ook het aandeel HBO'ers en WO'ers onder de instromers neemt toe. Veel voorkomende opleidingsrichtingen zijn openbare orde en veiligheid, economie/administratie/commercieel en sociale/welzijnsstudies. Ongeveer driekwart van de instromers werkte al voor ze bij de politie aan de slag gingen, meestal in de marktsector. Daarnaast kwam ruim Io\% net uit de schoolbanken.

De meest belangrijke expliciete pullfactor is de inhoud van het werk. Daarna volgen de loopbaanontwikkelingsmogelijkheden, zelfstandigheid/verantwoordelijkheid, relatie met collega's en de werkplek/fysieke omstandigheden. Een analyse op subgroepniveau laat zien dat de pullfactoren manier van leiding geven, de communicatie en de flexibiliteit van de organisatie vaker door vrouwen worden genoemd. Jongeren (I5-24 jaar) noemen loopbaanmogelijkheden vaker dan de andere leeftijdsgroepen. zowel 45-54jarigen als de 15-24-jarigen noemen zelfstandigheid en verantwoordelijkheid vaker als pullfactoren. Hoger opgeleiden ( $\mathrm{HBO}$ en WO) vinden werkinhoud, ontwikkelmogelijkheden en zelfstandigheid veel belangrijkere pullfactoren dan de andere factoren. Bij lager opgeleiden spelen ook andere aspecten een substantiële rol bij de keuze voor een politiebaan.

Van de meer impliciete pullfactoren lijken meer contracturen, het verdienen van een hoger salaris en het kunnen werken in een baan met een hoger functieniveau voor een deel van de instromers een rol te hebben gespeeld bij de keuze voor een executieve politiefunctie. Uit de subgroepenanalyses blijkt dat vrouwen en niet-westerse allochtonen iets vaker hetzelfde of een hoger salaris zijn gaan verdienen. Vooral autochtone, lager opgeleide en jonge ( $15-24$ jaar) instromers zijn er qua functieniveau op vooruitgegaan door hun overstap. Echter, gaandeweg komt dit ook steeds vaker voor onder de 45-54-jarigen en de hoger opgeleiden.

De politie-uitstroom bestaat voor ruim twee derde uit executief politiepersoneel. Hiervan vertrekt gemiddeld iets meer dan de helft op eigen initiatief, ongeveer $30 \%$ gaat met (vervroegd) pensioen en tussen de I0\% en $20 \%$ wordt ontslagen of krijgt geen contractverlenging. In de vrijwillige uitstroom onder executief politiepersoneel zijn vrouwen behoorlijk en $25-44$-jarigen enigszins oververtegenwoordigd ten opzichte van het totale politiepersoneel dat werkzaam is in een exeuctieve politiefunctie. Politie-uitstroom blijkt een gemengd begrip te zijn: een derde tot bijna de helft van de uitstroom is in feite doorstroom naar een andere baan bij de politie (ander korps, andere functie, ander politieonderdeel).

Een aantal expliciete pushfactoren die een belangrijke rol spelen in het besluit om de huidige politiebaan op te zeggen zijn de loopbaanmogelijkheden, de inhoud van het werk, de wijze waarop de organisatie wordt bestuurd, de wijze waarop de direct leidinggevende aanstuurt en de resultaatgerichtheid van de organisatie. Bij vrouwelijke uitstromers scoort ook de pushfactor communicatie hoog, bij mannen de verantwoordelijkheid en zelfstandigheid. Opvallend is verder dat het combineren van 
werk en privé in de loop der jaren ook door mannen steeds vaker genoemd wordt. Daarnaast lijken ook de meer impliciete factoren het hogere salaris en een baan op een hoger functieniveau een rol te spelen bij het opzeggen van de huidige politiebaan. 



\section{Bijlagen}

\section{Bijlage B2.1}

Beroepen behorend tot de volgende beroepsgroepen:

\section{Aspirant politieagenten, soldaten en beveiligingshulpkrachten}

- Parketwacht politie

- Aspirant agent politie

- Militair lagere rangen dan onderofficier

- Portier (excl. hotel)

- Bewaker

\section{Politieagenten, onderofficieren en beveiligingsemployés}

- Bedrijfspolitieagent

- Bedrijfsrechercheur

- Particulier detective

- Militair onderofficier

- Rechercheur (excl. bedrijfsrecherche; middelbaar)

- Politieagent

- Wachtmeester

- Adjudant

- Wachtcommandant

- Postcommandant (politie)

- Leidinggevend beveiligingsbeambte

- Militair onderofficier

\section{Politie-inspecteurs en officieren}

- Militair officier (kapitein of lager)

- Rechercheur (excl. bedrijfsrecherche; hoger)

- Politie-inspecteur

- Leidinggevend militair officier (kapitein of lager)

- Adjunct-directeur gevangenis

- Hoofd veiligheidsdienst overheid 


\section{Tabel B2.2}

Ontwikkeling potentiële beroepsbevolking, 1996-2008

$\begin{array}{ccccccc}1996- & 1998- & 2000- & 2002- & 2005- & 2007- \\ 1997 & 1999 & 2001 & 2003 & 2006 & 2008\end{array}$

Potentiële beroepsbevolking (in personen)* $\begin{array}{llllll}10.550 .000 & 10.635 .500 & 10.764 .500 & 10.883 .000 & 10.945 .500 & 10.966 .500\end{array}$

$\begin{array}{lcccccc} & \% & \% & \% & \% & \% & \% \\ \text { Geslacht } & & & & & & \\ \text { Man } & 51 & 51 & 51 & 51 & 50 & 50 \\ \text { Vrouw } & 49 & 49 & 49 & 49 & 50 & 50\end{array}$

Leeftijd

\begin{tabular}{|c|c|c|c|c|c|c|}
\hline 15-29 jaar & 30 & 29 & 28 & 27 & 27 & 27 \\
\hline 30-49 jaar & 46 & 46 & 46 & 46 & 45 & 44 \\
\hline 50-64 jaar & 23 & 25 & 26 & 27 & 28 & 29 \\
\hline $\begin{array}{l}\text { Gemiddelde leeftijd } \\
\text { (in jaren) }\end{array}$ & 38,1 & 38,5 & 38,9 & 39,2 & 39,7 & 40,0 \\
\hline
\end{tabular}

\section{Herkomst}

Autochtonen

83

82

82

82

81

81

Westerse Allochtonen

$9 \quad 9$

Niet-westerse Allochtonen

8

8

9

910

11

Opleidingsniveau

Basisonderwijs

VMBO

HAVO + VWO + MBO

\section{2}

39

$\mathrm{HBO}+\mathrm{W} 0$

41

$19 \quad 20$

2
37
41
20

\section{2}

37

40

21

$\begin{array}{lll}1 & 1 & 1 \\ 35 & 33 & 32 \\ 41 & 41 & 41 \\ 22 & 24 & 26\end{array}$

De getallen in personen afkomstig uit de Enquête Beroepsbevolking van het CBS worden afgerond op 500-tallen.

Bron: CBS (EBB) 
Tabel B2.3

Ontwikkeling werkzame beroepsbevolking, 1996-2008

\begin{tabular}{|c|c|c|c|c|c|c|}
\hline & $\begin{array}{l}1996- \\
1997\end{array}$ & $\begin{array}{l}1998- \\
1999\end{array}$ & $\begin{array}{l}2000- \\
2001\end{array}$ & $\begin{array}{l}2002- \\
2003\end{array}$ & $\begin{array}{l}2005- \\
2006\end{array}$ & $\begin{array}{l}2007- \\
2008\end{array}$ \\
\hline \multirow[t]{2}{*}{$\begin{array}{l}\text { Werkzame beroepsbevolking } \\
\text { (in personen) }\end{array}$} & 6.284 .000 & 6.677 .500 & 6.968 .500 & 7.018 .000 & 6.996 .000 & 7.334 .500 \\
\hline & $\%$ & $\%$ & $\%$ & $\%$ & $\%$ & $\%$ \\
\hline \multicolumn{7}{|l|}{ Geslacht } \\
\hline Man & 62 & 61 & 60 & 59 & 58 & 57 \\
\hline Vrouw & 38 & 39 & 40 & 41 & 42 & 43 \\
\hline
\end{tabular}

$\begin{array}{lcccccc}\text { Leeftijd } & 28 & 27 & 25 & 24 & 22 & 22 \\ \begin{array}{l}15-29 \text { jaar } \\ 30-49 \text { jaar }\end{array} & 56 & 55 & 56 & 56 & 56 & 54 \\ \begin{array}{l}\text { 50-64 jaar } \\ \text { Gemiddelde leeftijd }\end{array} & 16 & 18 & 19 & 20 & 22 & 24 \\ \text { (in jaren) } & 37,3 & 37,7 & 38,1 & 38,7 & 39,5 & 39,9\end{array}$

\begin{tabular}{|c|c|c|c|c|c|c|}
\hline \multicolumn{7}{|l|}{ Herkomst } \\
\hline Autochtonen & 86 & 85 & 85 & 85 & 84 & 83 \\
\hline Westerse Allochtonen & 9 & 9 & 8 & 8 & 8 & 8 \\
\hline Niet-westerse Allochtonen & 5 & 6 & 7 & 7 & 8 & 9 \\
\hline \multicolumn{7}{|l|}{ Opleidingsniveau } \\
\hline Basisonderwijs & 1 & 1 & 1 & 1 & 0 & 1 \\
\hline VMBO & 28 & 27 & 28 & 26 & 23 & 23 \\
\hline HAVO + VWO + MBO & 46 & 45 & 45 & 45 & 45 & 44 \\
\hline $\mathrm{HBO}+\mathrm{WO}$ & 25 & 27 & 26 & 28 & 31 & 32 \\
\hline
\end{tabular}




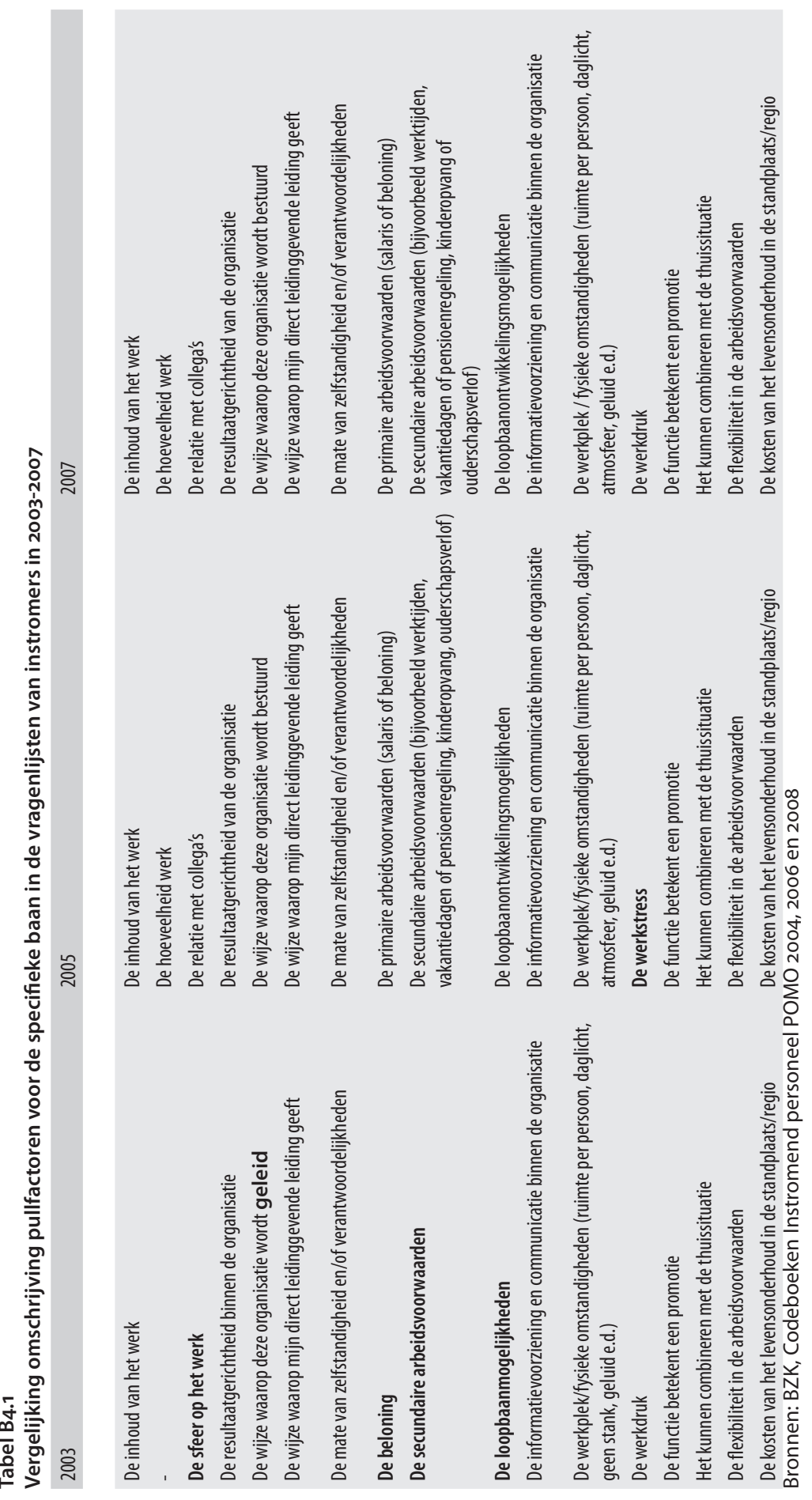

